\title{
The Linguistic History of Some Indian Domestic Plants
}

\section{Citation}

Witzel, Michael. 2009. The linguistic history of some Indian domestic plants. Journal of BioSciences 34(6): 829-833.

\section{Published Version}

doi:10.1007/s12038-009-0096-1

\section{Permanent link}

http://nrs.harvard.edu/urn-3:HUL.InstRepos:8954814

\section{Terms of Use}

This article was downloaded from Harvard University's DASH repository, and is made available under the terms and conditions applicable to Open Access Policy Articles, as set forth at http:// nrs.harvard.edu/urn-3:HUL.InstRepos:dash.current.terms-of-use\#OAP

\section{Share Your Story}

The Harvard community has made this article openly available.

Please share how this access benefits you. Submit a story.

Accessibility 
Michael Witzel,

Harvard University

witzel@fas.harvard.edu

\section{THE LINGUISTIC HISTORY OF SOME INDIAN DOMESTIC PLANTS}

From* ${ }^{*}$ the mist of times emerge our earliest Indian texts, the Rgveda (c. $1300-1000$ $\mathrm{BCE}$ ), composed in the Northwest of the subcontinent, and the Sangam texts (c. $2^{\text {nd }}$ cent. BCE - early CE), composed in the extreme South. They contain valuable materials in archaic Indo-Aryan (Vedic Sanskrit) and in archaic Old Tamil respectively. The former belongs, along with Old Iranian (Avestan of Zarathustra), to the ancient Indo-Iranian subfamily of Indo-European that stretches from Iceland to Assam and Sri Lanka. ${ }^{1}$ The latter belongs to the Dravidian family ${ }^{2}$ that is restricted to the subcontinent but may have relatives in Northern Asia (Uralic) and beyond. ${ }^{3}$

As for the plant names found in these old sources, it must be observed that recent advances in archaeobotany 4 indicate at least three major nuclei of food production in the subcontinent. They can be briefly characterized as follows.

In the west of the subcontinent, the food producing package was derived from that of the Middle East: winter wheat, goat/sheep, with the Indian addition of the Zebu and water buffalo. Wheat even has a Near Eastern name and it is not the result of local domestication as was sometimes thought; instead it took some 2000 years in the western border regions of Pakistan and Afghanistan before it was acclimatized to Indian climatic conditions. ${ }^{5}$

Second, there was a Lower Gangetic agricultural center with rice and water buffalo (c. $2500 \mathrm{BCE}$ ). Agriculture was first established only around $3000 \mathrm{BCE}$, in spite of what is now sometimes claimed by some local archaeologists. ${ }^{6}$ Indian rice (vrīhi, Oryza indica) is a hybrid of northern Indian wild rice, O. nivāra, and the southern Chinese domesticated variety, O. japonica (as recent genetic research has indicated. ${ }^{7}$

Third, there is a somewhat later upper South Indian center with intensive cattle herding and growing of millets, including an African variety. Around $1800 \mathrm{BCE}$, it spread southward and also northward into Malwa.

Fourth, there may have been additional indigenous centers of food production,

\footnotetext{
* The transcription followed in this paper is the standard scholarly one for Indian languages, thus $\overline{\mathrm{a}}=$ long a, $\overline{1}=$ long i (ee), $\overline{\mathrm{u}}=$ long u (oo), e, o (long e, o,), etc.; consonants: $\dot{\mathrm{n}}, \tilde{\mathrm{n}} \mathrm{n}, \mathrm{t}, \mathrm{d}$, ś, ș; however Dravidian/Middle Indo-Aryan: long ē, $\overline{0}$; Tamil alveolar $\underline{\underline{n}}, \mathbf{z}=\mathrm{r}+$ double underdot -- as in 'Tamil/Tamizh'. - Reconstructed forms are indicated by $*$; > means 'develops to', < 'is derived from'; $* h_{1-3}$ are the reconstructed IE laryngeals, similar to the Tamil âytam consonant. For ease of reading, $a$ is used (in reconstructions marked by * only) to indicate 'any vowel', instead of the linguistic shorthand V.

1 See Beekes 1995, Szemerenyi 1996. For material archaeology, see J.P. Mallory \& Adams 1997.

2 See now Krishnamurti 2003.

3 Such as the proposed Nostratic superfamiliy that includes IE, Dravidian, Uralic, Altaic, Afroasiatic and Kartvelian (Georgian). For Nostratic dictionaries, see http://starling.rinet.ru/main.html.

4 Fuller 2006, 2009.

5 Fuller Diss. London, and Fuller 2006, 2009.

6 Tewari, R. et al., 2009. -- However, see discussion by D. Q. Fuller, http://Archaeobotanist.blogspot.com/indian-archaeology-watch-lahuradewa.html.

7 Sato 2004, 2006.
} 
one in the east (Orissa/Jharkhand), and one in the west (W. Gujarat, S. Rajasthan). ${ }^{8}$

Both the earliest Indo-Aryan (often still, but erroneously called "Aryan") 9 and Old Tamil texts contain names of trees, plants and agricultural products that shed considerable light on the early history of plants in the subcontinent - and of the people who used them. In addition, the testimony of later texts and languages, down to those still contained, but hidden in modern ones will be used.

In this investigation, only some of the most important plant terms can be dealt with, especially those for barley, oats, millet, wheat, and rice, -- some of which have diverse, sometimes surprising origins in all the major 5 linguistic families of the subcontinent - and well beyond.

The largest of them, Indo-European, is represented in the subcontinent by the great IndoIranian subfamily that includes Iranian, Nuristani (Kafiri in northeast Afghanistan) and Indo-Aryan («Aryan»). East of Nuristani, there is the IA subdamilioy of Dardic which exhibits most of the developments seen in the rest of the Indo-Aryan languages. Dardic includes the languages spoken from the borders of Afghanistan to the eastern, Kisthwar dialect of Kashmiri, among others: Kalasha, Khowar, Shina, Kohistani, and Kashmiri.

Dravidian covers all of the south and some parts of Central India as well as the North Dravidian outliers Brahui in Baluchistan, Kurukh in N. Madhya Pradesh, and Malto in S.E. Bihar. The latter three have moved out of Central India into their current homelands only around 1000 CE. ${ }^{10}$

Besides the Indo-European and Dravidian families, there also is the Austroasiatic one, represented in India by the Munda languages ${ }^{11}$ of central and eastern India, by Khasi in the hills of Meghalaya and by Nicobarese. Another family is Tibeto-Burmese, spoken all over the northern sections of the Himalayan belt including Arunachal Pradesh and in the eastern states of Nagaland, Assam, Meghalaya, Manipur, Mizoram and Tripura. A fifth family is represented by Burushaski, ${ }^{12}$ a remnant language in Hunza (northernmost Pakistan), and finally there is Andamanese. To this, we can add substabtial evidence for remnants of lost families (see below).

As for Indo-Aryan, the diverse origin of names for agricultural plants is not really surprising because of the predominantly pastoral interests of the early speakers of Vedic. Differently from the frequently met with IE/IA terms for cattle, milk, horse, etc., agricultural ones such as 'barley', 'ploughing', etc. are significantly less frequent. Consequently, the multitude of Indo-Aryan words for plants that have come down to us stem from the other language families present then and especially so, from the now lost substrate languages. Linguistic investigation indicates that they covered large stretches of the subcontinent. ${ }^{13}$

Such local (substrate) words can be isolated from Indo-Aryan fairly easily by linguistic observations. They have unusual sounds and word structure, and there usually is a lack of a convincing Indo-European etymology tracing back the word to cognates in other IE

\footnotetext{
8 Fuller 2006, 2009.

9 The ancient Iranians (like King Darius, 519 BCE) also called themselves ariya/a ${ }^{i}$ riia.

10 Elfenbein 1987.

11 See now the comprehensive volume edited by G. Anderson, 2008.

12 See Berger 1998.

13 Witzel, M. 1999; cf. http://ejvs.laurasianacademy.com /issues.html.
} 
languages. For example, in Vedic Sanskrit a word like busa 'drizzle, chaff'14 is actually not allowed: it should have been buṣa with a retroflex ș (as in Kṛ̣na or bhāṣa). Indeed, the word is found in the non-IE Burushaski language as busa (and in neighboring Iranian languages). ${ }^{15}$

Many such words stick out immediately like the proverbial sore thumb, just as words with initial $n g-$, $n k$ - or mf- would do in English (Nkrumah, Zulu nkosi 'god', Mfume - now an American surname). The same applies to word structure. A Rgvedic name like Balbütha cannot be parsed according to Vedic or Indo-European rules: there is no IE/IA root word balb- and no suffix - $\bar{t}$ tha. The word goes back to an unknown, lost language of the Greater Panjab, about which more below. Unfortuantely, scholarship has not advanced that far in the analysis of Proto-Dravidian, and even less so in Munda, etc.

Now, as for the names of these domestic plants and agricultural terms, some important aspects of their early history in the subcontinent can be gleaned from the oldest, strictly transmitted oral texts, the Vedas (c. 1300-1000 BCE) ${ }^{16}$ down to the records of early historical times. ${ }^{17}$ Many of the agricultural terms found in the Vedas have survived until today, like yava 'barley' as Hindi jau.

As for Indo-Aryan, the early evidence can be counterchecked and expanded by attestations in medieval (MIA) and modern (NIA) Indian languages. This is especially useful when studying words that have been ignored in the religious and ritualistic Vedas but that are available in Middle or New Indo-Aryan languages, such as the Buddhist Pāli texts, the various Prākrts or modern languages like Hindi, etc., as compiled in R.L. Turner's Comparative Dictionary of Indo-Aryan languages $(C D I A L)$. For example, the old agricultural word for 'flour' turns up only in some of the modern Indo-Aryan languages, such as $\bar{a} t \bar{a}$ 'flour' in Hindi, etc. It goes back to the non-attested Vedic Sanskrit * ārta 'flour', CDIAK 1338, from $r t$ 'to grind.'18

The current investigation also includes the detailed study of agricultural terms (and their sources) in Hindi by C. Masica ${ }^{19}$ and its use by D. Fuller, ${ }^{20}$ whose discussion fortunately includes their respective area of origin. For IA, we have the etymological dictonary of Sanskrit by Mayrhofer ${ }^{21}$ and Turner's CDIAL. ${ }^{22}$ For Dravidian there is the etymological dictionary by Burrow and Emeneau ${ }^{23}$ - actually just an extensive list of

\footnotetext{
14 In the sequel, I frequently neglect (except in direct quotations) the Vedic pitch accents as they are of no consequence for loan words, thus busa instead of busá (cf. Kuiper 1991).

15 And, as loans in E. Iranian: Sariqoli bus and Waxi bis, cf. also Munda: Santali busu'b, see Pinnow 1959: 93 § 120; cf. EWA II 229 sq.; for a possible Munda origin (cf. Sadani bhusū) see Osada, IIJ 38, 1995.

16 For the Vedas and their strict oral transmission, see Witzel, M. 1997, http://www.people.fas.harvard.edu/ witzel/canon.pdf.

17 Texts before the first historical documentsts Aśokas inscriptions, c. $250 \mathrm{BCE}$ ), include the Buddhist canon in Pāli collected c. 250 CE under Aśoka, Pāninini's grammar and early commentaries of it (c. 350-150 BCE), the Indian epics (Mahābhārata, Rāmāyaṇa (c. 100 BCE), and a few texts such as the early parts of Kauțilya's Arthaśāstra.

18 Turner, CDIAL 1338 with discussion, *ārta 'flour', atța 'food' MBh., 'boiled rice' lex; Gāndhārī: Niya Doc.s; Gy. eur. aro, varo, vanro, etc .; Dardic: $\bar{o} t, \bar{a} t$, aṭ etc. K. abl. $\bar{a} t$; S. ato 'meal', L. ātā

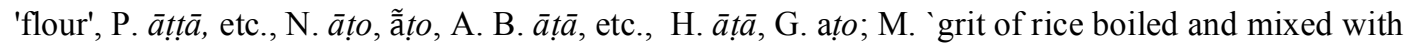
flour'.

19 Masica1979.

20 Fuller 2006, appendix.

21 EWA: Mayrhofer1986-2000.

22 CDIAL: Turner 1966.

23 DEDR: Burrow, T. and M.B. Emeneau1984.
} 
related words-- and the recent reconstruction of Proto-Dravidian by Bh. Krishnamurti. ${ }^{24}$ The situation is much worse for Munda, ${ }^{25}$ Burushaski, ${ }^{26}$ and Tibeto-Burmese. ${ }^{27}$

One constant problem to be taken into account in the following discussion is that (a) the exact botanical identification of certain plants (especially of the various sorts of millet/sorghum) are not always reliable and (b) that an older designation of a cereal plant may be used for a newly introduced one, as is especially frequent with millets, but which also occurs across species boundaries such as between barley and rice.

To indicate how people felt around 1000-500 BCE, we luckily have some Middle Vedic texts, composed in North India, which name seven or ten important domestic plants (saptá grāmyấ oṣadhayah). The 7 plants are: rice, barley, sesame, mung beans, millets, wheat, lentil, other beans, and the pulse Dolichos biflor, ${ }^{28}$ and the 10 are: vrih $i$ rice, Oryza sativa; yáva barley, Hordeum vulgare; tíla sesame, Sesamum indicum; mấsa mung beans, Phaseolus mungo; áṇu millet, Panicum miliaceum; priyángu millet, Setaria italica (L.), Panicum italicum; godhû́ma wheat, Triticum aestivum/sativum; masû́ra lentil, Lens culinaris; khálva beans, Phaseolus radiatus, a variety of Phaseolus mungo = $m \bar{a} s ̦\left(\right.$ ?); khalá-kula Dolichos biflorus L. ${ }^{29}$ These Vedic lists begin with the food most favorable to the gods (and humans), rice and barley.

Below, in the apendix, plants and their names are ordered according to their geographical origin, their first attestation in texts as well as the place of the texts' composition, so that a fairly detailed picture emergess for the ultimate 'origin' and the first textual attestation in time ${ }^{30}$ and space ${ }^{31}$ of Indian plants.

Likewise, in this paper, these data are presented in roughly historical and geographical order, starting in the northwest and west of the subcontinent with our oldest testimony.

\section{$\S 1$ The Northwest: RagVeda AND Other Vedic TEXTS}

In this section our earliest texts are used: the Rgveda in archaic Vedic Sanskrit, and also the closely related Old Iranian Avesta of the Zoroastrians, as well as the languages that have descended from Old Iranian, Old Indo-Aryan and from Nuristani, such as modern Persian, Pashto, Hindi, etc.

A study of the names for domesticated plants indicates that the Rgveda contains just a few words that can be traced back to Indo-Iranian and Indo-European, and that most of the others are of local origin. This is not surprising for a mainly pastoral people such as the Indo-Iranians and Vedic Indo-Aryans.

The small number of inherited Indo-European terms rapidly diminished as the Indo-Aryans and pre-Iranians moved further away from their common home in northern and later in southern Central Asia as well as in the Hindukush area. However, copious residues of Indo-European terms are still found today in the Hindukush-Pamir area, that is in the local Iranian, Nuristani or the nrothwestern Indo-Aryan Dardic languages

\footnotetext{
24 Krishnamurti 2003.

25 David Stampe, online dict.: http://ling.111.hawaii.edu/austroasiatic.

26 Berger 1998.

27 Benedict 1972.

28 Taittirīya Saṃhitā 5.2.5.5, Śatapatha Brāhmaṇa 14.9.3.22.

29 W. Rau, 1997: 205.

30 See Witzel 1997; 2006.

31 See Witzel 1987.
} 
(Kashmiri, Khowar, Kalasha, etc.). Such terms rapidly and increasingly diminish in number, and finally disappear, in the other Indo-Aryan languages of the subcontinent, beginning with the Panjab.

This, incidentally, is a clear indication that both the names as well as the population that spoke early Vedic came from the northwest - Afghanistan and beyond. ${ }^{32}$

We begin, thus with the IE-derived names of domesticated cereal plants. As indicated, one has to be constantly aware of the frequent shift in meaning from older designations for ceral plants to more recently introduced (or to those that have gained greater importance, such as from 'grain' > 'rice', or the typical shift in meaning seen in British English corn 'wheat' > American English 'maize.'

\section{$\S$ 1.1. GRAIN, CORN}

Old Indo-Aryan (OIA) has two general words for 'grain, cereals, corn'. ${ }^{33}$

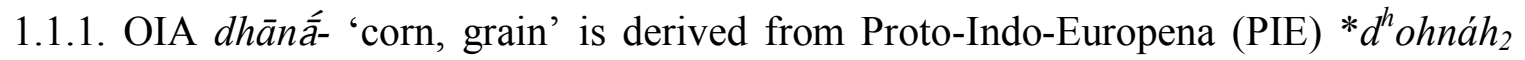
'corn'. It is still found in the Indo-Aryan (Dardic) language Khowar dān 'parched grain' and in various Iranian languages. ${ }^{34}$ The word and its derivatives are found in virtually all IA languages, if arranged as per R.L. Turner's ${ }^{35}$ usual order of presentation, from west to northwest, Himalayas, then back west along the Gangetic plains, and finally south to Gujarat, Maharastra, Goa and Sri Lanka (CDIAL 6777):

RV, Vedic, Pali, Prakrit. - Gy(psy) - K(ashmiri) - S(indhi) - P(anjabi) - Pah(ari)

- N(epali) - A(ssamese) - B(engali) - Or(iya) - Bi(hari) - Mth (Maithili) Bhoj(puri) - Awadh(i) - H(indi) - G(ujarati) - M(arathi) - Si(nhala).

In other words, the term is found all over the general IA area except, inexplicably, in the some of the Northwest (Dardic), which may be a feature of lack of collections in the dictionaries or these smaller tongues.

1.1.2. Another word for grain is: PIE $* s{ }^{e} s y \bar{a},{ }^{*} s^{e}$ syóm 'corn' $>\mathrm{OI}$ sasyám 'grain to be harvested, seeds', sasá- m. 'food, herb, grass, seeds'. ${ }^{36}$ (CDIAL 13294), ${ }^{37}$ found also in

32 The opposite, a spread of these terms out of India, falls prey not just to Occam's razor: why did only these early, PIE terms survive, and why only outside India? For this pseudo-problem, note the well established linguistic data and conclusions, in: Hock 1999, Witzel 2001, 2005. Such data are habitually disregarded and overlooked, for example by B.B. Lal (2001-2) who neglects the most typical IE tree bhürja, the birch tree (found only in highland Kashmir above 7000 feet) that has a typical IE name 'the white one'. The climatic conditions make it impossible for the word to have been exported form the plains of northern India -- unless one goes back to the glacial maximum of the last Ice Age, much too early for any IE language. -- In addition to the birch, the IE word for 'oak' may be contained in parkati > 'ficus infectiora', (EWA II 194 s.v. plaksa), and that for 'willow' in vetasa > 'Calamus rotang' (EWA II 578), if so, then both with change of meaning in the Indian climatic context. As in some cases of crop names (see below), more such IE tree names are retained in E. Iranian and Dardic in the Northwest.

33 Many of the following IE details are taken from Wiczak 2003.

34 Such as Avestan dānō-karš(a)- 'carrying grains', Khotanese dāna- 'grain, corn', Sogdian $\delta$ ' $n$ 'grain of cereal' and note Ir. *dānā- in the Pamir languages; further attested in a number of other IE languages: Hittite, Luwian, Lithuanian, Latvian; cf. Semitic *duhn-u 'Sorghum vulgare' and Dravidian *tin-ay 'Italian millet.' Cf. below $\S 5.1 .4$.

35 See Turner, CDIAL 6777 dhāná ‘corn, grain (esp. parched grain)' for details about the various NIA languages including cf. various derived forms: P. dhānã parched grain'; H. gur-dhānīf. 'parched wheat and molasses', etc. and CDIAL 6778 dhānyà 'pertaining to grain'.

36 Avestan hahiia, hayhuš; further Hittite, Celtic > Provençal, Catalonian, Spanish; Gaulish, Welsh, 
Iranian and other IE languages.

1.1.3. Perhaps related is PIE *sīto-, *sītyo- 'corn' > OI sît(i)yam n. 'corn' (lex.), 'ploughed' in Pāninini Khowar siri 'barley', Kalasha šilí 'millet.' ${ }^{38}$ However, the root *sa ,to sow' as seen in Skt. sìtā, sìrā, etc., is not from IE but stems from a Central Asian substrate and thus is not related to IE *seh ${ }^{\prime}$ to sow' : ${ }^{*}{ }^{s e ́} h_{1-} m$, 'grain' as in Latin sèmen 'seed.' 39

1.1.4. Importantly, the following old IE words for 'grain' are no longer found in IA, but have been retained only in the western/northern arc surrounding the Greater Panjab: *h$h_{2} a d$ - 'grain': Avestan $\bar{a} \delta \bar{u}$ - 'grain', Sogdian ' $d$ ' $w k[\bar{a} d u k]$ 'corn, grain, cereals, ${ }^{40}$ and, equally so, PIE * gŕhnom 'grain' > 'corn', the origin of English 'grain.'41

\section{$\S$ 1.2. BARLEY}

The most typical IE food grain was barley. It ultimately stems, along with wheat, from the Fertile Crescent. Its IE term yéwh ${ }_{1}$ os may originally just have meant "The Grass" as it is derived from the verbal root *yewh $h_{1}$ 'to graze.' It is also the most widely spread IndoAryan term for cereals. In the Veda, originally it was the most common food for humans and gods, later added to by rice. Barley, just like wheat (below), originally stem from the Near East.

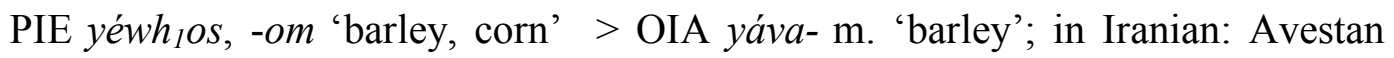
yauua- 'grains', yauua-ha- 'pasture'; Ossetic yäw 'millet.' ${ }^{2}$ In the subcontinent, barley is found from Nuristani and Dardic in the northwest all the way south to Sinhala (CDIAL 10431): RV, Pāli, Prakrit; Gypsy - Dardic (Kalasha, Shina, etc.) - Sindhi - LahndaPanjabi - W. Pahari - Kumaoni - Nepali - Assamese - Bengali - Bihari - Maithili - Hindi - O. Marwari - Gujarati - Marathi - Sinhala; in some cases the meaning of the word has changed as to include more recently prominent cereal plants. ${ }^{43}$

Breton; note the loan into Eastern Caucasian *sūs $V$ 'rye' > Chechen sos 'oats', etc.

37 sasá 'grain, food' RV. Or. sasa 'kernel, nutritious part'; A. xah 'crops'. - The derivative 13295 sasyá 'grain, fruit' AV., is found in K. sas 'beans or peas or lentils, etc. porridge' B. sẫ 'grain, fruit, fleshy part of fruit', Or. sẫ̄ $a$ 'kernel, nutritious part'; Old Si. hasa 'crop', Si. sas, has, as 'corn crop'. 38 Also found in Greek and its dialects Mycenaean, Delphian.

39 And in Old Saxon sāmo, Old High German samo 'Same,' as well as in Old Prussian, Lithuanian, Old Church Slavonic. - However note also the similar Munda terms $s \bar{l}$, see $\S 4$. 1.

40 Armenian, Lycian, Gothic, Tocharian. -- * $h_{2} a d h o r$ 'Triticum dicoccum'; -- Hittite, Armenian $<$ *had- 'grain'.

41 In Pashto zazay 'grain'; further in Albanian, Latin, Old Irish, Welsh, Gothic, Old English corn, Old High German, Old Norse, Lithuanian Latvian, Old Prussian, Old Church Slavonic, Russian, etc.

42 Further in Hittite, Greek zeiai pronounced [zdeiái/tseiái] 'Triticum monococcum', Cretan; Old Irish, Lithuanian jãvas 'Getreideart', pl. javaĩ 'Getreide'; Russian, Tocharian B $<*$ yewh h $_{1}$.

43 For details see CDIAL 10431 yáva 'barley,' attested from the RV onward. Changes in meaning are seen in European Gy. (eng. germ.) 'oats', Nuristani: Kāmviri juvór 'corn (maize).' Derivations (with modern reflexes) are the Late Vedic $10072 y \bar{a} v a$ 'consisting of or prepared from barley' KātyŚr., with reflexes in Sindhi and Nepali; the Late Vedic yấvaka- 'a particular dish of barley' Gaut.; the early post-Vedic 10439 yavāní 'a kind of bad barley' Pān. com., 'Ptychotis ajowan' Suśr. and the Vedic 10438 yavāgú 'rice-gruel(!)' TS. -- Further related is the post-Vedic CDIAL 10434 yavanāla 'Andropogon bicolor' Suśr., found from Lahnda jộ̂ul 'oats, a weed like oats' to N. junyālo, junelo 'big millet,' H. junhār etc. 'millet' and M. jõdhlī 'the grain Holcus sorghum;' cf. finally 10437 yavākāra 'barley-shaped' and derivatives, with meanings ranging from jowār, millet, to sorgum, 
The other PIE designations for barley are only preserved in the mountainous arc northwest of the Greater Panjab.

1.2.2. PIE * $\left(h_{2}\right)$ álb $^{h} i$ 'barley' > Iranian *arbusā $>$ Khotanese rrusāa, Wakhi arbasi 'Hordeum', Pashto ōrbūše 'barley'; further, found in Greel and Albanian; all derived from < PIE *alb os 'white'.

1.2.3 PIE * $b^{h}$ árs- 'barley' > Iranian: Ossetic Digor bor (xwar) 'millet'; Yazgulam vraxt 'flour' <*bršta. ${ }^{44}$

1.2.4. PIE *g' ${ }^{h} e ́ r s d^{(h)}$ - or ${ }^{*} g{ }^{\prime}{ }^{h} r o ̂ d^{h}$ - 'barley' > Iranian: Middle Persian jurtāk, zurtāk 'corn', Persian zurt, zurd 'a kind of millet', dial. jurdā 'corn'. ${ }^{45}$

1.2.5. PIE *kaskos 'barley' > Iranian *kaska- > Khotanese caska- 'corn', Munjan kosk 'Hordeum', Šughni čǔšč, Rušani čošč 'barley' etc., Persian kašk, Armenian. ${ }^{46}$ Note the unrelated Nuristani words (CDIAL 3112) Kati kāàco' 'millet', Waig. kā́c 'millet' (see $\S$ 2.4.6).

\section{$\S 1.3 . \mathrm{RYE}$}

Rye is a less respected cereal where people have other choices and then prefer wheat. Such was also the case in the Panjab and consequently the old IE word for 'rye' has sruvievd only in the Iranian speaking areas of S. Asia: PIE *rugh $i s, *^{h} r g^{h} y o s$ 'rye' > Old Iranian *ruǰika- > E. Iran. Šughni roy̌z 'ear of rye or rice', Wanetsi rō̌̌j 'ear of corn.'47 PIE * rugh is is, of course, the origin of English 'rye'.

\section{$\S 1.4$. OATS}

Oats, too, usually is a low-esteem cereal, also used for fodder. Two IE words may have perhaps survived in Vedic Sanskrit.

1.4.1 PIE *k'op[r] 'oats' > OIA śāpa- m. 'driftwood, drifted reeds'; Iranian: Alan zabar 'Auena,' Šughni sip(i)yak 'a kind of millet,'48 as in English dial. and haver, German Hafer.

barley, or even 'soft grass of high altitude' (Pahari). Prehistorically related is 10436 yávasa- 'grass' $\mathrm{RV}$ and its derivatives.

44 Further in Greek, Albanian, Latin, Oscan/Umbrian, Old Irish, Old Norse, Old English bere 'barley', Old Church Slavonic, Russian; Old Irish, Welsh, Cornish, Breton, Latin; -- cf. Semitic *burr-*barr'grain, wheat' as source or as loan from IE.

45 Also in Greek, Mycenaean, Albanian, Latin hordeum, Germanic * gerstō, Old High German, Dutch.

46 Or in Iranian $<* k r \check{s} a-k a-$; further Albanian, Tocharian B.

47 In Germanic: Old Norse, Old English ryge, Old Frisian, Old Saxon, Old High German; further: Lithuanian, Old Prussian, Old Russian; - cf. Afroasiatic: Egyptian r r $\underline{d} \underline{d} \underline{d}$ 'cereals', Hausa roogo; and East Caucasian * $r \partial \hat{c} \hat{c} V$ 'a kind of cereal (oats, rye). From Iranian stems Uralic words in Mordvinian, Komi, Udmurt.

48 From O. Iranian *sāpar-ku-, Persian $s a b z$ 'vegetable; grass', Pamir language: Rošani sabēc 'pod of bean'; -- further in Hittite, Greek, Middle Irish,Welsh, Cornish, Middle Breton, Breton, Old Norse, English dial. haver, Old Saxon, Old High German, Lithuanian šãpas 'stalk, branchlet, splinter.' Cf. EWA II 629, CDIAL 12387. 


\subsubsection{PIE *pūrós, -óm 'Triticum compactum' > OI pūra- m. 'cake' CDIAL 833.49}

1,4.3. The neighboring Iranian languages still have another variety: PIE $* h_{2}(a)$ wi $\hat{g}-i-/-s^{0}$ 'oats' > Iranian *avi[z]-sa- > Khotanese hau 'oats', Yazgulami wis 'Avena.' 50

\section{$\S 1.5$. MILLET}

There are many varieties of millet and sorghum. It is now clear that the IE speaking people already grew a variety of millet, perhaps broomcorn millet. ${ }^{51}$ (Other types of millet originated in India, China, and Africa, see $\S 2.4$.)

However the IE words for millet are only found in the Dardic NIA languages in the northwest of the subcontintent (and in Nuristani). They have been lost in the Greater Panjab, where they have been substituted by local (substrate) words.

1.5.1. PIE * $h_{2} a ́ r g{ }^{w h} 3: * h_{2}$ órg ${ }^{w h}$ eno- 'millet' > Nuristani *arjana- > Aškun az.ü, Kati awrí 'millet'; Dardic: Pašai aṛîn, Kalaša arin, etc. 'millet'. 52

\subsubsection{PIE *melH-i, ${ }^{\circ} n$-és 'Italian millet' > Dardic: Khowar blan 'barley.' 53}

1.5.3. PIE * $k$ 'ers- 'millet' is found only in other IE languages,${ }^{54}$ however, comparable are: Nuristani (Kāmviri) kārí ,millet' and Dardic designations of 'millet': Kalaša karas, Khowar khərāš, Phalura kāraž, Dameli káarac. ${ }^{55}$

Another PIE word for 'millet' is found only in the Iranian and Nuristani languages surrounding the Greater Panjab in the northwest.

1.5.4. PIE*'swah ${ }_{2} r_{2} h_{2}$ 'common millet' > Iranian $h w \bar{a} r \bar{a}->$ Alan huvar 'millet', Ossetic Digor xwar 'corn, grain, millet', Iron xor 'corn, barley Hordeum vulgare', Sogdian $\gamma w r-$

49 CDIAL 8331 pūra 'cake' Rāmāyaṇa, pūrikā 'cake' MBh, found from Kashmiri pūru 'a kind of cake fried in ghee' to Marathi purī. In IE it is seen in Greek, Germanic (Old English, English furze 'Triticum repens'), Lithuanian, Old Prussian, Church Slavonic, Slovenian, Czech, Russian. Cf. the non-IE Kartvelian (Georgian) $p^{\text {' } u r i ~ ' w h e a t, ~ w h e a t, ~ c o r n ' ~ w h i c h ~ m a y b e ~ l o a n e d ~ f r o m ~ G r e e k . ~}$

50 Also in Greek, Latin, Lithuanian, Latvian, Old Prussian, Slavic: Russian, etc.

51 See Fuller 2009: 3.

52 O. Iranian *arzana- > Persian arzan, etc. and East Iranian: Pashto ždan, Yidgha yūrzun, Wakhi yīrzn, Khotanese eysä, àysam 'millet, Panicum miliaceum'; also in Greek, Old Irish. See CDIAL 636 *arjana- 'millet', but cf. CDIAL 95 *aṇuni- 'millet', áṇu- in Nuristani árìn etc. 'millet', and in Dardic: Kalasha arín, etc.; see below aṇu §2.4.

53 In Greek, Latin milium 'millet', Old Norse, Lithuanian; -- etymology: IE *melh- 'to grind, mill'; or *melh ${ }_{2}-n$ - 'black', cf. OI śyāmăka- 'Indian millet / Panicum frumentaceum': śyāmá- 'black', opposite IE *alb ${ }^{h}-i$ 'barley' < IE *alb ${ }^{h}$ - 'white'. Cf. also Georgian meleuli, meleuri 'millet bound up in harvesting' from *meli 'millet' - Turner, CDIAL 10385: from Skt. mlāna- 'withered, shrivelled, darkcoloured', seen in Khowar blan 'a kind of barley.'

54 Hittite karas- 'wheat Triticum dicoccum or Triticum durum'; -- Italic: Oscan, Sabine, Latin Ceres 'goddess of fertility', Germanic: Old High German, German Hirse, Old Saxon.

55 Note also the similar, but not connected, CDIAL $3112 k$ áśa 'a grass used for mats, Saccharum spontaneum,' with meanings in Nuristani and IA from '(foxtail) millet', 'S. spontaneum', to 'a species of grass or reed' and Gujarati kās 'a kind of white grass'. Turner CDIAL regards the connection of Dardic kāraz, kāraž 'millet' as not clear. 
'barley', Middle Persian $x w \bar{a} r$ 'food. ${ }^{56}$ One may compare Nur. Kāmviri: r'oa, r'ov millet (Panicum mileacum). ${ }^{57}$

\section{$\S$ 1.6. WHEAT}

Wheat was the staple of the Indus Civilization (2600-1900 BCE), however, it is not attested in the RV but only in post-Rgvedic texts, and even then it remains just another ceral, listed way behind barley and the newly adopted rice (see above).

Curiously, it is not an IE or IIr word but an old Near Eastern loan word that has traveled east along with the plant, which was domesticated, like barley, in the Fertile Crescent in Neolithic times. ${ }^{58}$ It was first grown in the western piedmont areas of the subcontinent that had perennial rivers and primitive irrigation canals before it spread to the Indus plains. (There are remnants of another, equally ancient designations for wheat/grain in Burushaski. $)^{59}$ It is notable that the cultivation of wheat was arrested in the area west of the Indus for several thousand years, ${ }^{60}$ and that it spread further east and south only after extensive acclimatization around 2200 BCE.

OIA gōdhúma- (with a popular etymology meaning 'cow smoke'!) ${ }^{61}$ is an ultimately Near Eastern name. This is seen as a loan in Hittite kand, ${ }^{62}$ O. Egypt. xnd; Afroasiatic *hont- 'a kind of cereal' > Akkadian utțatu, Hebr. hitțā, Arab. hintat-;63 cf. also North Caucasian *henk ${ }^{w}-{ }^{*} h_{o n k}{ }^{w}$ - 'barley,' 64 and a supposed 'Anatolian' ${ }^{*}$ ghond $[\tilde{u}],{ }^{65}$ comparable with Drav. (Kanada) ${ }^{*} g \bar{o} d i$. A further development, east of the Fertile Crescent, was Iranian *gant-um. ${ }^{66}$

The tracks of both loan words differ: the form *gant-um entered via the northern Iranian trade route (Media-Turkmenistan-Margiana/Bactria-Sistan (while pre-Drav. gōdi

\footnotetext{
56 Or PIE *swer- > Iran. * $x^{v}$ ar- 'to nourish'; -- Albanian, Lithuanian, Latvian, Tocharian AB; further in Iranian and Baltic: Avestan $x^{v}$ arəna- 'food' > Slavic, Lithuanian; cf. also Semitic * $\hat{s}^{C} \bar{a} r-(a t-)$ 'barley' (lit. 'hairy'), Uralic *śôra.

57 However, this is derived from IA lāva ,reaping.' -- Finally, cf. Nur. tāj' 'ün sorghum tāji ,maize.

58 In the area west of the Zagros and south of the Caucasus, in the western Fertile Crescent. Some scholars had claimed, parallel to the recent, still fashionable denial of movements of people, a purely local development (cf. Allchin 1995 : 46, cf. Allchin, F. R. and N. Hammond 1978; Kenoyer 1998.

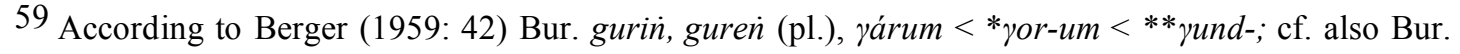
gur 'barley, wheat colored', bur 'buckwheat,' However, gur has Macro-Caucasian links: Basque gari 'wheat' < P. Eastern Caucasian * $\underline{G}$ ole 'wheat' (Bengston in Witzel 1999). These words are close to Afroasiatic * $g^{(w)} i / a r \sim$ garga/ir 'grain, bean', Semitic: Hebrew gērāa, Arab. z,arz,ar-, Chadic *('a)$g^{(w)} a / i r \sim *^{*}$ gargar: Hausa guro, Cushitic: Oromo garii 'seed', etc.; cf. also Afroas. * $g^{w} a r-$, gu/ar 'to collect, harvest': Chadic (Angas) gur, Somali gar, etc., all of which points back to an ancient Near Eastern source **qer/qend: for the variation of $r / n$ see Witzel 2003.

60 Fuller, D. Q. Dissertion and 2006, 2009

61 The unfamiliar *gantum/gandum > *godum was analyzed as go-dhüma 'cow smoke' (EWA I 498-

9, Kuiper IIJ 34, 1991, 119) which is as nonsensical as many such adaptations of foreign words (cf. Amer. Engl. wood-chuck, ultimately from a local Amerindian word, ösitomu).

62 Loaned from local *knt- 'rye or a similar cereal' > Hittite kanta-, Luwian, Dacian, Lusitanian > Latin, Spanish Portuguese; Tocharian B; also loaned into Uralic/Fenno-Permian.

63 As well as in Hausa, Somali, etc.; cf. EWA I 499.

64 In Avar oq, Bežit $\tilde{o} X$, Ubykh $X_{w} a$ 'barley'.

65 Thus, Harmatta, see EWA I 499; or Klimov's Proto-Kartvelian (Georgian) *ghomu.

66 As in Avestan gantuma-, Sogdian gantum vs. * ganduma- > Khotanese ganam, Pašto yanəm $(<$ * gandūma?), Yigdha gondum, Munjan yandám, Middle Pers. gandum, Baluchi gandìm, etc.; cf. Berger 1959: 40sq., EWA I 498.
} 
via the southen route). The Iranian form has also been taken over by the Drav. newcomer ${ }^{67}$ in the region, Brahui with xolum < IA * yolum (CDIAL 4287).

When the local pre-Iranian word *gantum entered the Panjab, it inexplicably changed its initial syllable *gan- to go-, thus *godum: the Pre-Iranian form *gantum should have resulted in Vedic *gan-tuma or *gan-dhuma. ${ }^{68}$ The change from -an- to -ois not typical for the Panjab but it found in the very sparsely reconstructable southern Indus language. ${ }^{69}$ The southern (Meluhhan) substrate form * gōdi must have influenced the northern *gantum/gandum so that the popular etymology go-dhüma 'cow smoke' was made possible. ${ }^{70}$ Notably, as mentioned, the word is not attested in the oldest text, the Rgveda. The change to *godum was perhaps due to a northward expansion, out of Sindh, of early Dravidian speakers at the end of the Rgvedic period. ${ }^{71}$ In the end, IA godhuma (CDIAL 4287) is found in Vedic and Nuristani and then from Dardic all the way south to Sinhala. ${ }^{72}$

This word joins a fairly large number of Central Asian words that have been taken over both by Iranian and Vedic from the Oxus civilization (BMAC) and its surroundings. ${ }^{73}$ Such terms include those for sheaf, seed, ploughshare, lynch pin, well, canal, yeast, bread, pillar, brick, house, wooden peg, sand, gravel, bowl, spit, axe, club, cloak, hem, coarse garment, cloth and needle, as well as words for hemp, cannabis and mustard (and extend into religon as well).

It appears that the greater Hindukush/Pamir area was and is a hotspot of linguistic diversity, which is also reflected in the names of domesticated plants of the area. We have IA languages (including Dardic like Kashmiri, Khowar, Kalasha), and west of it the third branch of IIr (Nuristani), further, the Eastern Iranian languages like the remnants of Sogdian (Yaghnobi) and Saka (Sariqoli), and the isolate Burushaski. The latter has yielded some rare loans already in the oldest Indian text, the Rgveda: busa 'chaff' (see above) or kilấla 'biestings'), which is in need for more study. ${ }^{74}$

\section{$\S 2$. THE NORTHWEST: SUBSTRATE WORDS IN INDO-ARYAN PANJAB AND BEYOND}

67 Brahui entered the Baluchistan area only about 1000 BCE (Elfenbein 1987), and thus has no Old or Middle East Iranian loans, but only recent ones from Baluchi, itself a late west Iranian immigrant language as well.

68 Cf. CDIAL 4020 Skt. (lex.) gandhālu 'fragrant rice', Pashai gandár 'a kind of grain'.

69 See Witzel 1999. A study of the substrates in Sindhi would be welcome in this respect, but has not even been proposed, except by my friend and collaborator F. Southworth 2006: 151.

70 This influence may be due to a post-Indus period, late Rgvedic Dravidian influx into the Panjab, as is visible in loan words (Witzel 1999). The precise nature of this influx and influence remains to be investigated.

71 See Witzel 1999.

72 CDIAL 4287 'wheat' (Yajurveda Saṃhitās)VS. Pa. gōdhūma, Gāndhārī: NiDoc. goduma, gohomi, goma, Pk. gōhūma, Gy. gišu, gēsū, gihu, giu, etc. 'wheat, rye'; -- Nuristani: gōm, gūm, etc. -- Dardic:

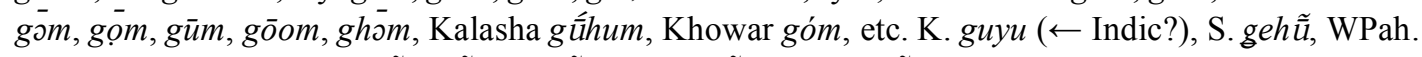

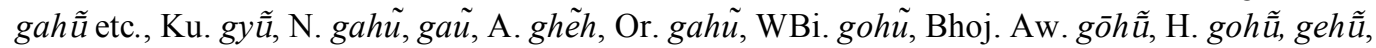

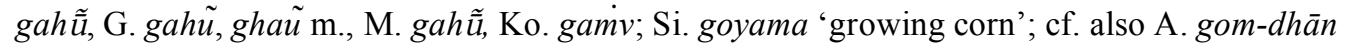
'maize'; B. gom, gam 'wheat', Or. gahama, EBi. gahum, gohum, Mth. gohum, gahūm.

73 See Lubotsky 2001; Witzel 1999, 2003.

74 Also found in Dardic and Nuristani, EWA II 358. See now H. Berger's detailed dictionary in Berger 1998. Cf. however also Tamil kizāan 'curd', DEDR 1580. 
As indicated, the use of local, indigenous plant names in Indo-Aryan languages is steadily increasing when moving away from the Northwest and into the subcontinent. Apart from the just mentioned Central Asian loanwords in Vedic Sanskrit and the western Asian word for 'wheat', there is another strong substrate in the Rgveda. It is a purely local one, representing the lost substrate language of the Greater Panjab. Some 300 words $^{75}$ in the RV belong to this group. As mentioned earlier, they do not fit IE/IIr patterns.

Many of them stem from the unknown prefixing Indus language(s), and from an equally unknown, generally North Indian substrate ('Language X,' as reflected in Hindi, etc.). They are joined, later on, by those from Dravidian which was not present in the Panjab until well after the Indus period, and also those from the Munda languages.

These words span all of local village life, from plant and animal names to the 'small tradition' of religion and ritual. They will have constituted the lost language of the northern Indus Civilization and its Neolithic predecessors. ${ }^{76}$ As they abound in Austroasiatic-like prefixes, I have (somewhat unfortunately) chosen to call it ParaMunda. ${ }^{77}$ It indeed resembles Munda in its typical use of prefixes (as in English for--give, for-get, be-get, be-head) but it does not overlap with very much as only a few words so far can be shown to have the typical Munda - $n$ - infixes. Further, it has to be noted that the Munda languages have been recorded only over the past 200 years and a gap of some 3000 years of unrecorded developments separates them from the time of the RV. Perhaps we should simply call this language the Kubhā-Vipāś substrate (taken from the Kabul river and the Beas). Its plant names include those of vegetables, cereals, trees and so on. Some of them are treated in the sequel.

The linguistic results can now be correlated with the archaeobotanical study of plants as carried out by Dorian Fuller. ${ }^{78}$

\section{$\S$ 2.1. BARLEY}

The indigenous word for barley has one such Para-Munda prefixes. It is attested in Late Vedic as kulmāṣa, which compares with other words in $-\bar{a} s ̣ a,-\bar{a} s \bar{a}^{79}$ such as māṣa 'beans'. CDIAL has 3349 kul-māṣa 'half-ripe barley' ChU, 'sour gruel of fruit juice or rice' Suśr. Pa. kummāsa 'junket'; Pk. kummāsa 'grain such as beans slightly wetted'; Si. komu 'junket'. It thus survives today only at the southern end of the subcontinent, in Sinhala, -- which is a typical case for the spread and survival in retreat areas of terms that have been substituted by later ones.

\section{$\S$ 2.2. WHEAT}

The word for wheat has been treated above $(\S 1.6)$. It is a West Asian loan word (CDIAL

\footnotetext{
75 See list in Kuiper 1991, and cf. http://www.aa.tufs.ac.jp/sarva/materials_frame.html.

76 Ravi phase in the Panjab, early Mehrgarh in Baluchistan, Birrana/Farmana in Haryana.

77 Even prominent linguists, such as the Dravidianist Krishnamurti (2003) and the Pāninian specialist Cardona 2003 have not understood the clearly stated difference between Proto-Munda and Para-Munda and have, accordingly, misrepresented and criticized the evidence, especially with regard to ParaMunda prefixes. This problem will be discussed separately, elsewhere. In contrast, Mayrhofer, $E W A$, consistently and correctly speaks of a 'prefixing language'.

78 See his detailed abstract in Fuller 2006, 2009.

79 See the numerous cases listed and discussed in Kuiper 1991.
} 


\section{7 gōdhüma).}

\section{$\S 2.3 . \mathrm{RICE}$}

As discussed in detail below ( $§ 4.1$.$) , rice (Oryza indica) is an indigenous domestication$ of the lower Gangetic plains. Consequently, there are some designations that do not have IA/IE etymologies.

The botanical term for 'wild rice' is still the same as the Vedic one (in the Yajurveda Saṃhitās): CDIAL 7571 nīvấra 'wild rice' VS. ${ }^{80} \mathrm{We}$ may however also compare DEDR 3614 Ta. navarai 'a kind of paddy', etc. ${ }^{81}$ These Drav. terms, restricted to the literary languages, do not have a Proto-Drav. origin. Both the IA and the Drav. words must instead go back to a local substrate, obviously that of the Gangetic plains.

The old IA word for Oryza indica is CDIAL 12233 vrinh ' 'rice' AV, though its descendants have disappeared from IA except for Sinhala viya 'growing rice' and for some northwestern languages. IA vrïhi is even found in Nuristani: Kt. wric , ŕ $\vec{l} c$ 'barley' :: Kāmviri wrúji 'husked uncooked rice', Pr. wuzî́, as well as in NIA Dardic: Shina brĭ̌ŭ

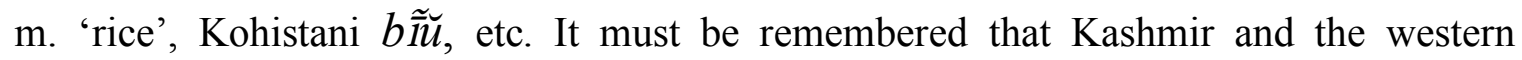
Piedmont have early archaeologcial evidence for rice, which may have reached there along the Himalayan belt, where rice is grown in all suitable plains and river valleys, or via the Indus civilization whose late stage has evidence for rice. ${ }^{82}$

\section{$\S 2.4$. MILLET}

The various types of millet have diverse origins: barnyard millet from China, $\mathrm{N}$. Japan, broomcorn millet from the N. Caucasus, and foxtail millet from Bactria. Tropical millets stem from India and from Africa (sorghum). This has to be taken into account of any discussion of this wide spectrum of dissimilar plants. From China also stem Panicum miliaceum and Setaria italica. ${ }^{83}$ However, the Archaic Chinese words have no similarity to the Indian ones, and anyhow, ${ }^{84}$ a long stretch of Central Asian lands and the Hindukush separate them from the Indus area.

Other tropical millets such as sorghum, pearl millet, and finger millet came from Africa, and were found in Gujarat by 2200-1700 BCE. ${ }^{85}$ Millet was, thus, to some extent, a "new" import at the time of the Late Indus civilization; ${ }^{86}$ (cf. below, § 5.1. for Dravidian).

\footnotetext{
80 Further: nīvāraka Suśr. Pa. nīvāra 'wild rice'; K. niwar 'a kind of hardy rice growing at high altitudes'; H. nyār m. 'wild rice'; G. navār, namār m. 'rice growing spontaneously'. A derived form is 7605 naivārá 'made of wild rice' TS. B. neyāl 'rice — straw, cord made of rice-straw, straw- rope'.

81 Further: nakarai a kind of rice. Ma. navira, naviri, nakara a rice that ripens within two or three months, navara; Paspalum frumentaceum (?), Tu. navara a kind of grain; navare 'a kind of rice'. Te. nivari, nivvari 'Oryza.'

82 From IA stems CDIAL 9331 bhaktá 'food' RV., 'meal, food' > modern IA bhāt, etc.

83 Fuller 2006, 2009: 5; Fuller, The Archaeobotanist 25 Aug 2009.

84 Karlgren 1923, no. 543 *liang < ,liang 'millet, sorghum', 1095 *,tsi 'common millet', 1051 *, tsi< tsiək 'panicled millet, god of agriculture', $903 *, s u^{\sim}<d^{\prime} z^{\prime}$ 'iuet 'glutinous millet', $135 *^{*} i^{w_{o k}}$ 'rice, millet', $914 *{ }^{*} s i{ }^{w_{O}}$ 'glutinous millet.'

85 Fuller 2006, 2009: 8.

86 Southworth 1988: 665; Randhawa 1980-1986; summarized by Meadow 1998, Meadow and Patel 2003, Fuller 2006, 2009.
} 
Millet was important, especially in the savannah and drier regions, as it can be grown outside the preferred Indus growth period in winter (wheat, barley). In S. Asia its spread more or less coincides with the increasing spread of rice, ${ }^{87}$ which has markedly influenced the archaeologically attested emigration of Late Indus people towards the Gangetic plains, and towards Gujarat.

Some of the words for millet, such as anu, priyarigu, kanku, seem to be interrelated. They will be discussed next. The words aṇu and priyangu are relatively old, as they occur already in Vedic (Yajurveda Saṃhitā).

§ 2.4.1. CDIAL 192 ánu 'the grain-plant Panicum miliaceum' VS. Pk. aṇu, anua, anuā 'a sort of edible grain'; also: 195 *anuni 'millet.' 88 Surprisingly both words have been preserved only in the northwestern areas of the subcontinent in Nuristani and Dardic, but have been substituted by other terms elsewhere.

$\S$ 2.4.2. CDIAL 8976 priyángu 'Panicum italicum' VS, priyaingukā 'P. italicum' SāmavBr. Again it has been preserved only at the rims of the subcontinent, in Kashmiri, Marathi and Sindhi, and has been taken over into some Iranian Pamir languages. ${ }^{89}$

Ved. priyaingu $u^{90}$ seems to have been changed by popular etymology, like several other agricultural terms dealt with earlier ( godhūma, gōdi). ${ }^{91}$ The designations Ved. anu and *anuni (CDIAL 195) point to a contamination or cross of *kangu and *-(k/g)aingu and IA aṇu, thus: kangu : *angu : Ved. aṇu ${ }^{92}$

$\S$ 2.4.3. However, *kangu is attested with some divergent IA forms, -- always a good indication of varying local substrates: *kankuni, *kanguni, *tanguni (CDIAL 2606). Accordingly, a northwestern *kaikun, a central-northern *kangun, an eastern north Indian *tangun can be reconstructed for the pre-Vedic period.

They are superficially similar to some Drav. and Munda words: Dravidian DEDR 1084 kaìgu (Tam. kaìku), DEDR 1242 kampu (= Skt. kambū Hemādri), and ProtoMunda *gañ(-)gay. ${ }^{93}$ These words cannot easily be traced back to a single source. Hindi kangni can be compared with IA *kankunī CDIAL 2606, less so with Tamil kampu and

\footnotetext{
87 Kenoyer 1998: 163, 173, 178, Glover and Hingham 1996: 413-441.

88 Phal. ạnu 'millet'; Nuristani and Dardic 195 *anuni: Kāmviri āń 'millet'; D. árīn 'millet', Kt. awrĩ $\overline{1}$, Dm. ärín, Kāmviri āne 'grain for eating'> Kal. arín, Kho. oḷin,. etc.; all <*aḍin. Cf. Sh. āno 'Indian millet.'

${ }^{89}$ Further: Pa. piyarigu 'a panic seed, a medicinal plant'; Pk. piamgu 'millet'; K. pinga f. 'P. italicum'; M. $p \tilde{g} g v \bar{\imath},{ }^{\circ} g \bar{\imath}$ 'heart—pea, Cardiospermum halicacabum', pīgvẽ, ${ }^{\circ} g \tilde{e}$ 'its seed'; Si. piyan̆gu 'millet', puvan̆gu 'the plant Sinapis nigra.' Imported into E. Iran.: Shgh. pinj̆ 'Panicum italicum', Wj. punjev. $90_{E W A}$ II 190.

91 If it originally contained the substrate prefix *pər-(Kuiper 1991: 42f.), then reinterpreted as *priya+gu 'dear cow.'

92 Kuiper 1991: 38 on the loss of initial consonant $k$-; note also CDIAL 112 an்kürá 'sprout' Un. S. ãgūru m. 'sprout'; L. angurī 'blade of corn when it first appears', P. angūūi, ungurī, ãgūr 'granulation in a healing sore'; H. $\tilde{a} k \bar{u} r$, ${ }^{\circ} r \bar{a}$ m. 'sprout', next to *prānkiūra (for which see Kuiper 1991 on a substrate prefix *por-) .

93 Southworth 1988: 660, Zide, A. and N.H. Zide 1973: 8.

97 Note also i-kóngó in the language of the Ekonda, (Lakes Tumba and Leopold II area). The same word is shared by their Pygmy neighbors, the Batswa.
} 
Munda *gain(-)gay. The ultimate source of these words may have had a form such as **kaì-Ca ( $C$ indicating an uncertain consonant).

Indeed, the original source of kanku- and its derivatives lies in Africa. It is known that African millet was imported into India before 1900 BCE. As expected then, **kan-Ca and even kangu is reflected in Bantu --itself a latecomer in E. Africa-- where we find Proto-Bantu *kangu and *pungu. ${ }^{77}$ Agriculture had spread to the area around 3500-2000 BCE, though the arrival of Bantu speakers in East Africa is later. ${ }^{98}$ Even Proto-Bantu *kangu goes back, thus, to an earlier East African substrate.

In short, all major language families of S. Asia have taken over the word from an unknown, East African source, though once it had arrived in India, various local developments in early Dravidian and Munda took over, resulting in the curent forms. A clear difference between northern and eastern/southern forms is visible: PDrav. *kampu is opposed to PMunda *gangay, while the IA forms stand in between the two.

$\S$ 2.4.4. Further substrate words in Vedic texts include the following, first of all, again, millet, which occurs in two forms, one IA, the other two from a substrate. CDIAL 12667 śyāmâkka 'the millet Panicum frumentaceum' VS. is clearly derived from Vedic śyama 'black', though the reconstructed variant *s'yammäkka points to a separate origin or development. ${ }^{101}$ The words are attested in

Nur. ( $\rightarrow$ Pashto) - SLPWPahNOrBiMthHGMSi

$\S$ 2.4.5. The other word for 'millet, bajra' is from a substrate as well, though already attested in Late Vedic: CDIAL 9201 *bājjara 'millet', HŚS varjarit102 (cf. § 3.2). The

\footnotetext{
98 Ehret 2002.
}

101 CDIAL: Pa. sāmāka' P. frumentaceum', Pk. sāmã̃a $a$, etc. S. sã̃̃o; 'P. frumentaceum and its grass'; WPah.bhal. śāmāu m. 'a kind of darkish grass'; N. sāmā 'a weed among rice'; B. sāmā 'millet'; Or.

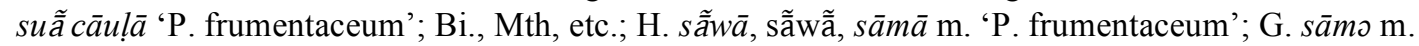
'inferior kind of self—-sown grain'; M. $s \tilde{\tilde{a}} \bar{a}, s \bar{a} v \bar{a}$ m. 'P. frumentaceum or miliaceum', Si. hämi, amu 'the grain Paspalum scrobiculatum'; -- further Wg. šamāk, šamäk 'oats'; L. savẫk, savāk 'the grass P.

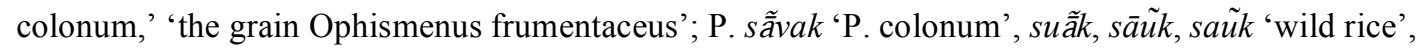
soak 'a kind of millet'; --however, *śyāmākka $\rightarrow$ Psht. šamāxa, šamūxa; cf. CDIAL 12668 * śyāmākatrna 'straw of a kind of grain'. M. sāvyān 'straw of Panicum frumentaceum'.

102 S. bājhari, $\underline{b} \bar{a} j h i r \bar{r},{ }^{\circ}$ ro 'the grain Holcus spicatus'; L. bājrāa, bājhrāa, ${ }^{\circ} r \bar{l}$ 'spiked millet'; P. bājrāa, ${ }^{\circ} r \bar{l}$ 'millet', N. bājuro, B. bājrāa, Or. bājarāa Bi. bājrāa 'millet', bājrī 'a small pea'; Mth. bājrāa 'millet',

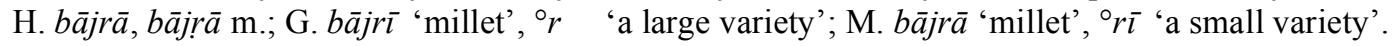


word is attested from the W. Panjab to Maharastra.

\section{LPNBOrBiMthHGM}

2.4.6. A special case is CDIAL 3112 kấśa 'a grass used for mats, Saccharum spontaneum'; it is found from Late Vedic onward (Kauś. Sūtra, Pa. Pk, etc). EWA I 345 states that its origins are unclear, rejecting earlier Drav. claims. The word is found from Nuristani and Sindhi to Gujarati. ${ }^{103}$ However, it can be added that the Nur. form $(k \bar{a} \dot{c}-)$, along with Vedic $(k \overline{a s} a)$ point to an Indo-Iranian reconstruction *kāc'a-. The word the may be another older, BMAC loan.

Nur.; -- SLPKuNABOrBiMthHG

$\S$ 2.4.7. The early word CDIAL 5827 tilá 'Sesamum indicum' AV., *tilaka, *tilla has been regarded as a Munda word. ${ }^{104}$ However, one must not forget the Mesopotamian word for sesame, ellu, whose exact origin (why loss of $t$-?) and spread to Mesopotamia remain unclear. There is a number of related words in IA (jar-tila 'wild sesame', tilvila) ${ }^{105}$ that belong to the prefixing language that forms a substrate in early and later Vedic. The word tila is attested from Kashmiri to Sinhala ${ }^{106}$ and suvives in the modern tel 'oil' as well.

\section{KLPWPahKuNABOrOAwBiMthBhojHOMarwGMSi; $\rightarrow$ Mesopotam.}

$\S$ 2.4.7 Hindi kodon, CDIAL 3515 kodrava 'grain eaten by the poor' Mbh., cf. koradūṣa 'idem' Suśr., kodravaka KŚS; and cf. DEDR 2163 Tam. kural, Kan. korale, korle; Konda koren 'a grain'.

$\S 2.4 .8$. Finally, there are many words for 'grain' which I leave out here, and there also is maize, newly imported from the Americas just half a millennium ago. It may serve as a good example of how a new crop is assimilated into the Indian linguistic orbit. The designations for 'maize' are found (for IA) in CDIAL 5005a *challī 'maize,' 9879 markaka 'Ardea argala' and 10434 yavanāla 'Andropogon bicolor', cf. Suśr., yōnala; with which compare also Dravidian DEDR 2896 Ta. cōlam, connal 'maize, great millet, Sorghum vulgare.'

103 Nur.: Kt. kā̇c د 'millet', Wg. kāà; S. kã̃hu 'S. spontaneum', ${ }^{\circ} h \bar{l}$ 'a species of grass'; L. kã̃h f. 'S. spontaneum'; P. kẫh, kāhl' 'S. spontaneum', kāh 'a kind of reed'; Ku. k kẫs 'a kind of grass used for religious purposes'; N. kã̃̃s 'S. spontaneum', A. kãhuwā, B. kās, Or. kāsa, kāiśa, kāãca, Bi. Mth. kās,

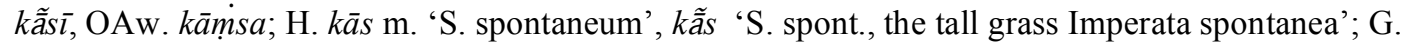
$k \bar{a} s \mathrm{~m}$. 'a kind of white grass'. -- Connection of Dm. Gaw. kāraz, Sv. kāražz 'millet' is not clear, as are Iranian forms in $-h$-, see $E W A$ I 345.

104 Kuiper 1955: 157. A Drav. source (T. Burrow BSOAS xii 142, 380) is, as per Turner CDIAL, less likely. 105 See discussion in Witzel 1999, 2004.

106 Pa. tila 'sesamum plant', 'its seed', Pk. tila 'the seed', K. têl, S. tiru 'plant and seed', L. P. WPah. Ku. N. A. B. til 'the s. seed', Or. tila, OAw. tila; H. til m. 'sesamum plant and seed, a minute fragment'; OMarw. tila 'small particle'; M. tīl 'sesamum seed', Śi. tala 'plant and seed'. - P. (Dogri) tir-caoli 'sesamum and rice with sugar'. - Further: Or. tila 'a species of sesamum seed'; G. tala $\bar{a}-$ tådl $\bar{a}$ 'as distinct as sesamum and rice, separated, dispersed'; M. till 'a small white kind of sesamum'. - Finally: Ku. $t \bar{l} l$ 'sesamum seed', Bi. $t \bar{l} l$, tilllı 'species with a white seed'; Mth. $t \bar{l}$, tila ' 'sesamum seed'; Bhoj. tìli; G. til, tal 'sesamum', talī 'a small variety.' 
Apparently all tehse words have been taken form older designations for cereal plants. The common NIA word makai (or similar) is derived from CDIAL 9879 markaka 'Ardea argala'. ${ }^{107}$

\section{§ 3. The Gangetic Plains: ANOTher nUClear AREA AND "LANGUAGE X"}

In his 1969 study ${ }^{\mathbf{1 0 8}} \mathrm{C}$. Masica has investigated the origins of agricultural terms in Hindi and found that some $30 \%$ of them are of unknown, «Language $\mathrm{X}$ » origin, while only 9.5\% are from Drav. and 5.7\% from Munda. His result could be broadened considerably if one would take into account the neighboring IA languages, as Franklin Southworth, David Stampe and this author are currently carrying out in our online substrate dictionary (TUFS, Tokyo, in progress, http://www.aa.tufs.ac.jp/sarva/entrance.html. ${ }^{109}$

However, agricultural terms in Tharu are from IA. The Tharu, an agricultural tribe in the Nepalese and adjoining Indian lowlands at the foothills of the Himalayas, have been long time local residents (and are immune against malaria). They now speak a northern Indo-Aryan language close to Maithili, Bhojpuri and Awadhi. Their language has a voluminous substrate. ${ }^{10}$ The designations for cereals are bājrā 'millet', dhān 'rice', makai 'maize', gehūm 'wheat'.

In contrast, the isolated Kusunda language in the hills of Nepal surprisingly has independent terms. ${ }^{111}$ The Kusunda were, until recently, hunter and gatherers who interacted with villagers to aquire cereals. One must wonder from which substrate language they derived their agricultural words, such as khərwi, khərugəi 'wheat', khaidzi food, cooked rice (cf. $k h a \partial-d-i$ 's/he parches grain'). However rãko, ranikwa 'millet' seems related to Proto-Austroasiatic * rkəw, Munda runkub for 'rice,' pointing to an earlier Munda occupation of the plains south of Nepal. ${ }^{112}$ The Kusunda even have a native word for the agricultural latecomer, ip $2 n$ 'maize', usually called makai in IA. Further research is necessary to elicit more terms from the c. 20 scattered surviving speakers in central and western Nepal.

Some of the Gangetic substrate words have already been discussed as they appear in Vedic texts $(\S 1)$. However, one set of Gangetic substrate words in Vedic, has geminate consonants that are fairly rare in Vedic: 113 such as seen in pippala 'fig' RV : (su-)piṣpala AV, MS, guggulu 'bdellion' AV,PS : gulgulu KS, TS; kakkața PS KSAśv. : katkața 'a bird' TS, This is echoed in language ' $\mathrm{X}$ ' by a few agricultural substrate words that contain such geminates. As mentioned, one word for cereals is *bäjjara or IA *bājara 'millet' CDIAL 9201 bājjara, which turns up, slightly Sanskritized in a Late

107 Dardic: Sh. măkăi, K. maköyü etc. S. makāī, makī, makăn̄ī, L. makaī, P. makaī, makkī, mak, Ku.

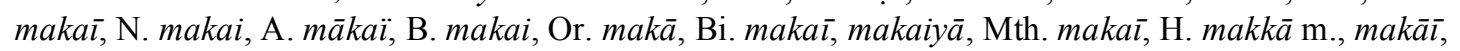
G. makāī, makai, M. makā; cf. markațaka, *markakakaṇa, *markaka-tṛna.

108 Masica 1969.

109 See upper right screen of: http://www.aa.tufs.ac.jp/sarva/entrance.html; the starred items that Turner CDIAL found as non-attested in IA texts form its basis; however, this list has been cleared of all obvious IA words. The residue is expected to be from substrate languages, and also (when indicated) from Drav. and Munda as well as occasionally from Burushaski and Tibeto-Burmese. Additions from the various etymological dictionaries are in (slow) progress.

110 I have carried out a pilot project at the Asia-Africa Institute of the Tokyo University for Foreign Studies (TUFS ) in 2004, but have not yet found the time to edit and publish it.

111 Watters 2005.

112 Cf. Witzel 1999.

113 Especially of the mediae $(b, d, g)$. They are often replaced by two dissimilar consonants (Kuiper 1991: 67). 
Vedic text as HŚS: varjarī ( $§ 2.4 .5$.) It occurs from Sindhi to Marathi. ${ }^{114}$ CDIAL 9049 *phapphara 'buckwheat' is attested from Panjabi to Marathi. ${ }^{115}$ Another word for 'buckwheat' may be CDIAL 11313 varata. ${ }^{116}$

Other examples of Gangetic plant names include: Hindi piplī/pipplā $<C D I A L$ 8205 píppala- 'berry (esp. of Ficus religiosa)' RV.; pippali 'berry' AV., 'peppercorn, Piper longum' Rāmāyaṇa, pippali Āpast. ${ }^{117}$ is now found from Kashmiri to Konkani and Sinhala. Similarly, kaith < Skt. kapittha 'a tree, Feronia elephantum, wood apple' CDIAL 2749 (for which cf. also aśva-tthá), is seen from Nuristani and Dardic to Marathi. Further plants include 1693 udidda 'a pulse', 725 *alla 'name of a tree or plant', (Morinda citrifolia'), 9724 mattara 'pea'. ${ }^{118}$ However, 3061 käravēlla 'the gourd Momordica charantia' is probably derived from Dravidian, and 13482 *suppāra 'areca nut' (Kashmiri to Marathi) may be an old word, but the pratice of consuming it with betel leaves is only about 2000 years old in S. Asia, but earlier in S.E. Asia.

\section{$\S 3.1$. Tibeto-Burmese influence?}

Next to the isolated substrates of Tharu and Kusunda, anonther important factor is Tibeto-Burmese, spoken all along the Himalayan belt; it had some impact on IA vocabulary. ${ }^{119}$ For example, Tib.-Burm. speakers have left us some names in the eastern Gangetic plains, such as Kosala (Audh), Kauśiki (now the Kosi River), perhaps also Kāśi and Kauśämbi (now Kosam), that all seem to be based on Tib.-Burm. khu, ku 'river.' 120

Agricultural terms include: CDIAL 4749 Skt. cāmala or cāvala 'husked rice' and probably also PS śāli 'rice'. ${ }^{121}$ The derivatives of cāmala/cāvala are now found from Sindhi and W. Panjabi to Gujarati. ${ }^{122}$

SPLWPahKuNAOBBOrBiMthBhojHOMarwG

\footnotetext{
114 CDIAL $9201 *$ bājjara 'millet', see above, $\S 2.4 .5$.

115 CDIAL 9049 * phapphara 'buckwheat', P. phaphrā, phāphrā 'buckwheat'; WPah.jaun. phāphrā 'husk of wheat'; Ku. phāpar 'a kind of buck- wheat growing near the snow-line'; N. A. phāpar 'buckwheat'; M. phāprī f. 'a kind of pot-herb.'

116 v/barața 'seed of safflower' Gṛhyas., varațā lex., but note Dardic: Shina bərāo f. 'buckwheat' (= Bur. bəru); Bi. barrī, barre 'seed of safflower', H. barrai.

117 Probabably of non- Aryan origin EWA II 133; cf. piplu from a similar source?

118 Cf. also CDIAL 13552 sūjjī 'coarse wheat meal', *sōjjī; 10837 rōtța 'bread'.

119 Kirāta now designates the eastern Tib.-Burmese speaking Nepalese tribes of the Rai and Limbu; however, the Kirātas are attested since the Atharvaveda, see Witzel, M. Nepalese Hydronomy:

Towards a history of settlement in the Himalayas. Proceedings of the Franco-German Conference at Arc-et-Senans, June 1990. Paris 1993: 217-266;

http://www.people.fas.harvard.edu/\%7Ewitzel/hydro.pdf. For a recent discussion of Tibeto-Burmese homelands in the Himalayan region see van Driem 2006.

120 Witzel 1993.

121 EWA II 632, takes śāli, $A V$ śāri as unclear. CDIAL 4749 deliberates the same non-Aryan origin as tāndula, K. tomul 'uncooked rice,' perhaps having been contaminated, cf. also Dardic tor. tunōl; further: 12415 śāli 'growing or unhusked rice' MBh., Pa. sāli, Pk. sāli, Gy. sal, sáli; Nuristani: Ash. salima, Wg. šélī, šalimāa, Kt. šälí K Kāmviri śāli, śélí, Pr. šilí̄; Dardic: šâli 'growing rice', šāl, sōle,

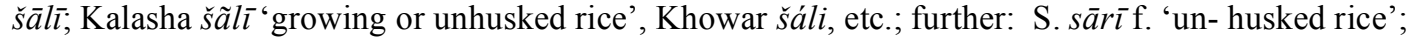
A. $x \bar{a} l i$ 'principal variety of transplanted rice'; B. sāl, sāil 'a kind of rice'; Or. sāll 'growing or unhusked rice', Bi. sāari, H. sāl, G. sāl, sāliyũu, M. sāl, sāḷ , Si. häl, äl.

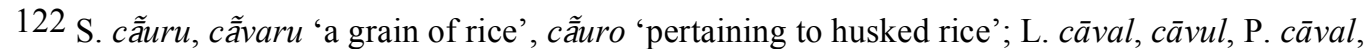
cāvar, cāul, caul, Ku. caũl, N. cã̃̄wal, cāmal, A. sāul, OB. tāula, B. cāul, cāl, Or. cāula, cāura, Bi. Mth. Bhoj. cāur, H. cã̃wal, cāwal, cāawar, G. cāval.
} 
The question remains whether the word is related to Tib.-Burm. * $d z a$ 'to eat', ${ }^{123}$ because one has to take into account Dravidian $D E D R 2391,{ }^{124}$ Ta. aval etc. 'usually flat rice', 2343 Ta. camai, 226, 268 Ta. avi (-v-,-nt). As initial consonant can disappear in Tamil, the related words in $c$-, $s$ - in Gondi etc. ${ }^{125}$ may preserve a form closer to ${ }^{*} c \bar{a} m a l$.

An obvious latecomer is cina 'the Chinese one', Panicum miliaceum'126 (see. $\S 2.4)$. Nevertheless it is found from Dardic all the way east to Bengali, and earlier in Buddhist texts. This serves as an opportune warning not to deduce ancient habitat simply from the attestation and location of modern languages: obviously, the northwestern languages were the first to receive the new variety, via the Silk Road or even earlier, via the Chinese-influenced Kashmiri Neolithic. ${ }^{127}$ The word has remained restricted to the northern IA languages:

\section{DardSLPWPahBOrBhojH}

\section{$\S$ 3.2. Cereal crops plants}

$\S$ 3.2.1. The word for barley, CDIAL 12561 s'ükaka 'barley, a bearded kind of wheat' Epic, lex., Or. sũā, suã 'a kind of grass and its seed, Panicum frumentaceum, sarsaparilla' may, however, ultimately be related to Skt. $s \dot{u} c \bar{l}$ 'needle' as it also designates the 'aw of grain.' (EWA III 494).

$\S$ 3.2.2. A classical Skt. word for wheat is CDIAL 11425 valla 'a kind of wheat' VarBriS., 'winnowing corn.' The double consonant, rare in early Skt., ${ }^{128}$ indicates a Gangetic origin (see $\S 2.4 .5$ ). The word is attested from Sindhi and Panjabi to Bihari and Gujarati. ${ }^{129}$

123 Bahing $d z^{\prime} a$; Nagari $d z^{\prime} y a$, Lushei śa, Burmese tsa, Garo $t s^{\prime} h a$; Kanauri $z a$, from TB *dza, see Benedict 1972, no. 66, p. 28.

1242391 Ta. aval 'rice obtained from fried paddy by pestling it;' avai (-pp-, -tt-) 'to pound in a mortar, crush, cuff, prod;' avaiyal well-husked rice. Ma. avil 'rice bruised and dried;' avekka 'to beat rice;' aval 'flattened rice obtained from paddy by pestling it.' Ko. kac av-(avt-) 'to pestle (millet) second time;' aky av- (avt-) 'to pestle (millet) third time.' To. af- (aft-) 'to pound with light strokes;' ofil 'puffed rice.' Ka. aval 'pound, beat;', 'pounding, beating in a mortar;' (also aval-akki 'rice bruised and crushed;' Koḍ. avl-akki 'rice fried and each grain pounded flat.' Tu. abepuni, abeyuni, abeccuni 'to beat or pound rice.'

125 Kol. cavli mortar; Nk. savli, Pa. cavil; cavkol 'pestle.' Ga. savul 'mortar,' savkol 'pestle,' savvul 'mortar,' savkōl 'pestle;' Go. sahkī, sāhkī, sahki, cahki, hahki, etc. (cf. 2799 Konḍa sonki, Pe. henki).

1264842 cina 'Panicum miliaceum', 'aka, cinnaka 'a particular grain', ciñāka 'fennel' lex. Further: cinna lex., 'aka Buddgh. Hybrid Skt.; Pa. cinaka 'a kind of bean'; S. cino m. 'the millet Panicum italicum'; L. $\operatorname{cin} \tilde{a} \tilde{a}$ 'P. miliaceum', P. $\operatorname{cin} \bar{a}$ m., Ku. $\operatorname{cin} \bar{a}$. Note also: B. $\operatorname{cin} \bar{a} ;$ Mth. $\operatorname{cin}$ 'P. italicum, P. frumentosum'; Bhoj. cin 'a kind of grain'; H. ciña, cenā m. 'P. miliaceum'; WPah. bhal. cin e $i$ f. 'a kind of minute grain'; Or. cin̄ 'millet'; Bi. cin 'P. miliaceum', $\operatorname{cinh}, \operatorname{cin} \bar{a}, \operatorname{cinn} \bar{a}$ ' 'P. frumentosum'; Dardic: Khowar čin 'a grain like wheat but bigger', Sh. ciñ f. 'millet harvest', 'a kind of millet': < * $\operatorname{cin}(a) k \bar{a}$ ?

127 See Fuller 2006, 2009.

128 Witzel 1999.

129 Pk. valla 'a kind of grain', vāa $\bar{a}$ 'a kind of grain, millet'; S. vali f. 'heap of reaped ears of corn', L. $v a l ; \mathrm{Ku} . b \bar{a} l^{\text {' }}$ ear of corn', bālo, bālro 'crops'; N. bālo 'ear of corn', bāli 'cornfield, crops, harvest'

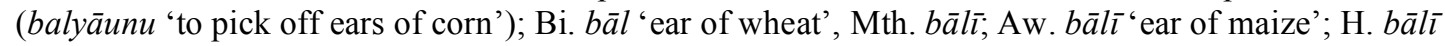

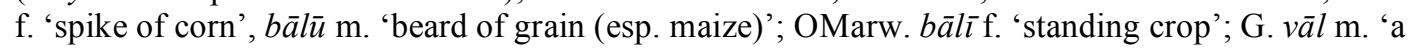
kind of pulse'; cf. 11426 *valla-puța 'grain pod'; valāta 'Phaseolus mungo' lex.; G. vālor 'beans in a pod', vālol, ${ }^{\circ} \mathrm{r}$ 'a bean, a kind of vegetable'. 
$\S$ 3.2.3. There are several words for rice that are different from vrīhi/*vrjjhi (above). CDIAL $2546 \bar{o} d i k \bar{a}, \bar{o} d \bar{\imath}$ 'wild rice' lex. appears in Assamese uri-dal 'a water grass producing grain like rice', uri-dhān 'wild rice'; and Bengali uri, uri-dhān 'wild rice' has been assumed to come from Munda. ${ }^{130}$

However, CDIAL 4020 gandhālu 'fragrant rice' lex. is obviously derived from Skt. gandha 'smell', and 14268 ấnjana, seen in Kashmiri anzonu, anzan 'a kind of rice with white grains which is soft and sweet-smelling when cooked,' has been compared with Md. andun, adun 'collyrium'.

The interrelated words for 'millet' have been dealt with earlier (§ 2.4.1-3.): CDIAL 2605 kañku, 3000 *kāìkuka, kāinguka.

\section{$\S 4$. MUNDA AND OTHER CENTRAL INDIAN PLANT NAMES}

As mentioned, the Munda languages are nowadays spoken in some parts of central and eastern India: N. Munda in the border region of Madhya Pradesh and Maharastra (Korku), in Jharkhand, Chattisgarh, N.Orissa, S.E. Bihar and the western parts of Bengal, while Southern Munda is spoken in S. Orissa and N. Andhra, where the Sora (Śabara) are already attested in early Skt. (Aitareya Brāhmaṇa 7.18) and in Classical Graeco-Roman texts.

They form one branch of the Austroasiatic family that also includes Khasi, Nicobarese, Mon, Khmer, Vietnamese. This branch is distantly related to the great Austronesian family which is spread most across the globe (next to post-1500 IE), -- that is from its home in Taiwan to Indonesia, Polynesia and Madagascar, in a two-four thousand years old migration achieved with the help of outrigger boats.

The study of the Munda family of languages of central and eastern India is even less advanced than at of IA and Drav., though there has been a recent, extensive update on individual languages. ${ }^{131}$ However, there still is no etymological dictionary of Munda; for the time being one can still utilize Pinnow's 1959 extensive discussion of Kharia and Austroasiatic, ${ }^{132}$ and the online dictionaries by David Stampe. ${ }^{133}$ It has to be noted that northern Munda (Santali, Mundari, Korku, etc.) is quite different from the little studied southern Munda languages (Sora, Juang, Remo, Gutob, Gta, etc.). The northern branch has considerably been affected by IA, especially in the vocabulary.

In general, it must be added that the ancient Mundas were culturally much more sophisticated than usually assumed. ${ }^{134}$ Their homeland has been sought in S.E. Asia or, recently, inside India. ${ }^{135}$ It has long been shown that the early Munda speakers had words for rice farming. ${ }^{136}$ While japonica rice spread out of the Yangtze basin, Oryza indica is a

\footnotetext{
130 See discussion in Witzel 1999.

131 Gregory D. S. Anderson (ed.). The Munda Languages. London and New York: Routledge 2008.

132 Pinnow 1959.

133 David Stampe, online dict.: http://ling.111.hawaii.edu/austroasiatic cf. http://www.aa.tufs.ac.jp/sarva/materials frame.html (Austroasiatic).

134 Such as e.g., in Parpola1994.

135 See now P. Donegan and D. Stampe, http://ling.111.hawaii.edu/austroasiatic/AA/rhythm1983.pdf.

136 Zide \& Zide 1976.
} 
hybrid of a local wild rice. ${ }^{137}$ The linguistic data ${ }^{138}$ support these two areas of origin of cultivated rice: the words for rice in Austronesian do not correspond to words for rice in Austroasiatic. ${ }^{139}$

\section{$\S$ 4.1. RICE}

In northern and eastern India, rice cultivation has been said to emerge by the early $3^{\text {rd }}$ millennium ${ }^{140}$ though some earlier dates have recently been given (see above $\S 0$ ). ${ }^{141}$

The following words are strongly attested for Proto-Munda (and even for the rest of Austroasiatic): ${ }^{142}$ baba 'paddy', gele 'ear of paddy', jain 'grain seed', sii 'plow', tutu 'pestle', seel 'mortar,' loyon 'wet paddy field', etc. The important words for husked rice and its plant are N. Munda cauli etc., S. Munda runkkub etc. (husked); N. Munda baba etc., S. Munda keroin, kondem etc. (plant). ${ }^{143}$

The Proto-Austroasiatic form for husked rice is * rkəw. ${ }^{144}$ Obviously, the Kusunda words rãko, raíkwa 'millet' (above) are related to the Munda ones, with the usual shift in meaning seen in cereals. The Vedic substrate word vrīhi, which must go back to *vrijjhi, subsequently transmitted to Nuristani (Kati) wric, Pashto, Persian, etc., is somehow related to these forms, and also to Old Japanese uruchi $(<*$ uruti, *wuruti), even if the intermediary forms are not clear. ${ }^{145}$

In addition to the words for husked rice (N. Munda cauli etc., S. Munda runkkub etc.) and the rice plant (N. Munda baba etc., S. Munda keron, kondem etc.) we also get several words unrelated to other language families.

$\S$ 4.1.2. Paddy: So. sārō/ sār 'paddy'. Sa. Horo huru 'paddy, the rice plant (Oryza sativa, L.)'. Mu. huru (K) 'rice'. (equals Mu. baba) Bh. huru 'rice'. Tu. huru 'rice'. So. sarō/ sar (D) 'paddy'. Kh. kõsrỗ pē? 'rice prepared for making beer'. Mu. kōsōrã kōsõ:rã 'rice or millet cooked for brewing'. Mu. kōsrã 'to parboil rice for making beer'. $\S$ 4.1.2 So. ba.ba (M) 'cooked rice'. (only in children's speech), Kh. $b a$ ? 'rice in the hull, paddy'. Ju. bua 'rice', derived from ba.ba, Mu. ba.ba 'the rice-plant, paddy (Oryza sativa, Linn.), or rice in the husk'. Ho ba.ba 'the rice-plant, paddy (Oryza sativa, Linn.), or rice in the husk'. Ku. ba.ba 'cauli rice'

137 Sato 2004, 2006.

138 For Munda plant names and loans into other Indian languages see now Osada 2006.

139 Osada 1995: 143 sqq.

140 At Chirand; further east at Sarutaru and Daojali, see Allchin \& Allchin. The rise of Civilisation in India and Pakistan. Cambridge Univ. Press 1982. See now Hingham, C. Languages and Farming Dispersals: Austroasiatic Languages and Rice Cultivation, In: Bellwood and Renfrew 2002; latest update by Fuller 2009.

141 Fuller 2006, 2009.

142 Details in Osada 1995: 143 sqq., 185 with related words in other Austroasiatic languages and in Austronesian, all the way to Taiwan.

143 'cooked rice': cauli Mundari, caole Santali, cauli Ho, rumku Kharia, run்kub Juang, ronko Sora, rünk, -ajan் Gorum, rko', -ro Gta', runku, i்kuk Remo, rukug Gutob, ? Korku; --'rice plant' Mundari baba, Santali horo, Ho baba, Kharia ba', Juang bua, Sora səro, kondem, Gorum kundem (-ar), Gta' condia', kia, ja (note Tib.-Burm. *dža? see § 3.1.), Remo keron, -ker, Gutob keron, -ker, Korku baba. 144 Osada 1995: 186. Not yet aware of Osada 1995, etc. I have come to similar conclusions, see Witzel 1999.

145 Detailed discussion in Witzel 1999, though still assuming, with then current archaeology, just one locale for the origin of rice, in S. China. Note Austronesian * beras and Tibetan hbras (also in Burushaski). 
$\S$ 4.1.3 'cooked rice' : Sa. daka 'cooked rice'. Mu. daha 'cooked rice; bee egg'.

$\S$ 4.1.4 'cooked rice': Sa. jagu 'cooked rice'. Mu. jagu 'cooked rice'.

$\S$ 4.1.5 'porridge, broken grain': So. kurul kul 'porridge, cooked rice soaked in water, rice gruel'. Mu. khudi $\sim k u d i$ 'broken grains', for which compare Drav. forms (§ 5.1.2.).

$\S 4.1 .6$ 'rice, flattened' : Sa. tabēn 'flattened rice'. Mu. tabēn 'flattened rice'.

$\S$ 4.2. Millet. As we have indigenous tropical millets in India, it is not surprising to find Munda words for them, such as Sa. gundli 'millet'. Mu. gundli 'millet'; and for 'millet sp.' Sa. iṛi 'kind of millet'. Mu. ịri 'kind of millet'.

\section{$\S 4.2$ Nahali}

The c. $24 \%$ substrate found in the Nahali (Nihali) language of Central India has many words for plants (and animals) that cannot be linked to IA, Drav. or Munda. A few prominent ones (including some imported plants) include the following words. ${ }^{146}$

āndij 'root like sweet potato', badágo 'guava' (cf. 9125 bádara- n. 'fruit of the jujube tree?), baru 'mulberry' (cf. various trees CDIAL 5872), butu 'kind of grass', bhed(a)rā 'potato' (!), bōy 'grass, fodder' (cf. DEDR 4535, grasses), dotako 'edible root', dhāwrā 'gum tree', dhongāri 'type of grass', gugudo 'edible root', hardo 'tumeric', jiryāngā 'tomato'(!), jodu/jüd 'bamboo', jhappon 'mushroom', khila 'parched rice', khude 'gourd', lubā 'incense', malkā 'pea (pod)', māyko 'mahua tree' (cf. DEDR 4772?), óhan 'mortar (with pestle)', oró 'millet, jawar' (cf. § $3.2 .3 \bar{o} d \bar{l}$ 'wild rice'?), phellyā 'groundnut', phendrā 'vine', raymony $\bar{a}$ 'wild thorny bush', rițha 'soap nut', sokor $\bar{a}$ 'bread', sidu 'mahua wine', sundu 'pod for beans', chāg $\bar{a}$ 'variety of thorny grass', chepiy $\bar{a}$ 'variety of grass', chunco 'a vegetable', chundu 'bean' (cf. CDIAL 4856?), tamāko'o 'tomato'(!), tāmku 'tobacco'(!), tāndur 'rice, cooked rice', tó 'ear (of corn)'. Nahali gele 'maize' is from Korku, gohũ 'wheat' from IA, and many other common plants are loanwords from Munda, Drav. or IA.

\section{§ 5. DraVidian}

The evidence for plant names in the South of India is similarly difficult to describe. Most of the peninsula, except for the Munda languages, is or was covered by Dravidian languages. However, these too families have not been studied as extensively as the IE (Indo-Aryan) languages of the subcontinent. We have comparatively less tools, and they are less well developed than the IA ones. Worse, the study of substrates in the area of Dravidian languages is almost non-existent. ${ }^{147}$ Interestingly, an Australian substrate ${ }^{148}$ has recently been discovered in S. India, -- something we would have expected anyhow, given the history of human settlement 'Out of Africa,' and the subsequent peopling of South Asia, Southeast Asia and Australia. This has by now been confirmed both by archaeological and genetic evidence.

\footnotetext{
146 From Mundlay 2006. See: http://www.aslip.org.

147 For an early attempt see Zvelebil, K. 1970, 1990 on a Nilgiri substrate, cf. Witzel 1999, and the discussions of place names in: Ramachandran and Nachimuthu 1987.

148 Blažek 2006. For a substrate in the Nilgiris, Zvelebil 1970, 1990: 64, 68 sqq; Witzel 1999.
} 
The Comparative (etymological) Dravidian dictionary by Burrow and Emeneau $(D E D R, 1984)^{149}$ is more of a somewhat disparate collection of data instead of a truly etymological dictionary that explains all parts of a word (root, stem, ending) under one head word, as has been done in the IA dictionary of Mayrhofer (1986-2000). ${ }^{150}$ A new version of $D E D R$ with Proto-Dravidian etymological identifications and word analysis has been envisioned for 2004, ${ }^{151}$ but it has not yet emerged. We can glean some data from Krishnamurti's book on the reconstruction of Proto-Dravidian. ${ }^{152}$

However, there are wide error bars in Krishnamurti's data. As in all reconstructions, the time frame of protolanguage is not one of 10 or even a 100 years span but it can cover much more, just as even 'current' English includes the antiquated forms of Shakespeare just as well as current slang. For example, reconstructed Vulgar Latin will have an 'emperor,' who before Caesar Augustus was just a temporary supreme army commander (and, thus, in Classical Latin). In the same way, Krishnamurti's reconstruction of Proto-Dravidian surprisingly has kings, palaces, forts, moats and cities, ${ }^{153}$-- all of which does not fit the arcahaeology of South India before 1000 BCE, when just pastoral and small agricultural village communities existed. Proto-Drav. is to be assumed for a much earlier period, well before his reconstruction of iron *cir-umpu (DEDR 2552) ${ }^{154}$ that is first attested archaeologically at c. 1200 BCE (Hallur, Karnataka).

Instead, Krishnamurti offers some very vague dating only, ${ }^{155}$ based on the antiquity of Proto-Drav. versus its reconstructed daughter languages Proto-South Drav. I and II and on some references to Drav. words in Vedic (in a post-1000 BCE text): the split of South Drav. I and II «could precede the period of the Aitareya-Brāhmana by at least four to five centuries, i.e. around the eleventh century BCE...» Surprisingly, Krishnamurti denies ${ }^{156}$--without giving any reasons-- the reconstruction of cultural terms in three subsequent stages discussed by F. Southworth. ${ }^{157}$

Secondly, it must be observed that these agricultural terms are often heavily biased towards the literary South Dravidian languages (Tamil-Malayalam, Telugu, Kanada, Tulu), but are not all-Dravidian (including northern languages such as Gondi, Kurukh, Brahui, etc.). This bias leads to reconstructing merely a period (South Dravidian I and II) that is much later than Proto-Drav., which is assumed to have existed around 4000 BCE by Zvelebil, and well before the second millennnium BCE, or rather in mid-third millennnium BCE by Southworth.

All of the above is crucial when evaluating Drav. plant names. Some apparently wiedespread terms may be much later than Proto-Drav. and may reflect only the languages of the southern tip of the subcontinent.

\footnotetext{
149 DEDR: Burrow, T. and M.B. Emeneau 1984.

150 EWA: Mayrhofer 1986-2000.

151 Krishnamurti 2003: 502.

152 Krishnamurti 2003. For a detailed list of Proto-Drav. words (flora, fauna, agriculture, etc, see Southworth 2005: 257-281; cf. p. 79, and 2006: 134-141.

153 In his draft, he even had an 'emperor'(!); see now Krishnamurti 2003: 7 sq., p. 15.

154 Krishnamurti 2003: 10.

155 Krishnamurti 2003: 501 sq.

156 Krishnamurti 2003: 15 n. 16.

157 Southworth 1995: 258-77, 2005: 242, 245, assumes Proto-Drav. at 3000-2500 BCE, and S. Drav. at 1500-1000 BCE, and Zvelebil 1970: 18, 1990 at c. 4000-3500 BCE.
} 
In general, technical terms related to agriculture include (as per Krishnamurti 2003: 8 sqq) the reconstructed words for ploughing *uz DEDR 688, yoked plough *cer 2815, dry and wet cultivation *pan- $\partial$ 'cultivated land' 3891; *pun 'dry land' 4337; *polam 'field' 4303; *kaz-ət 1355, *key-m 1958 'wet field'; *way-ə 5258, rice seedlings for transplantation $\tilde{n} \bar{a} t u 2919$, etc.

Among other flora (Krishnamurti 2003: 12) may be mentioned: black pepper *mil-əku 4867, cardamon *ēl-ə 907, which Krishanmurto says «seem native ... at least in south India.» The words for banana are *wāz-a 5373, ar-ənttiti 205. They are of great interest as the plantain is a plant that ultimately stems for New Guinea; it was spread westward by sea trade early, so that it is archaeologically attested as far as in W. Africa by $500 \mathrm{BCE}$. Its original eastern term is derived, via Indonesia, all the way from the place of origin, as reflected in IA: CDIAL 2712 kadala, kadalí 'the banana plant Musa sapientum', MBh. Suśr., and *kadali. ${ }^{158}$ In addition to *wāz-a 5373, ar-əntți 205 , there is a handful of Drav. words for the plantain/banana, but they do not overlap with IA kadal-/ kètak-.

Another interesting word is that for sugar cane, *kar-umpu 1288, *cet-əkk 2795. The Drav. words are quite different from *tu- in Austroasiatic and in Tibeto-Burmese (Newari): DEDR 387 Ta. àlai, 1414 Ta. kannal, 2795 Ka. ceruku sugarcane, 4916 Ta. muñci.

The «early attested" (Krishnamurti 2003) word for 'ginger', however, goes back only to a Middle Indo-Aryan singivera or S. Dravidian form: the Greek loanword ziggiberis, pronounced [tsingiberis] ${ }^{159}$ is ultimately related to S. Drav. *cinki-wèr (weer 'root'), Tam., Mal. *ciñci- > Pāli singivera (artificially reconstituted as Skt. śrngavera, EWA III 495).

The the areca nut at-ay-kkāy $D E D R \quad 88$, is reconstructed by Krishnamurti for Proto-Drav. This may well be so, however, the use of betel leaves together with areca is a later development and only about 2000 years old.

The Drav. word for areca, at-ay-kkāy, does not fit the northern substrate words seen in Indo-Aryan: CDIAL 13482 *suppāra, 3440 krmuká, 4219 guvāka, gūvāka, 5400 jhōda 'betel-nut tree', 5776 tāmbūlá 'betel, betel leaf' Suśr. ${ }^{160} 9213$ *bāru 'betel leaf,'161 $12046 v \bar{t} t \bar{i}$, all of which go back to local northern substrate languages or were imported from S.E. Asia along with the practice.

\section{$\S$ 5.1. MILLET}

As indicated, there are many types of millets. As far as South India is concerned, we have indigenous tropical millets but also an early import from China and Africa (before 1900 $\mathrm{BCE})$. This must be taken into account when evaluating the Dravidian terms.

\footnotetext{
158 From Austroasiatic, with different prefixes, such as ke-lui, te-lui. See KEWA I 150 with lit.; Pa. kadali 'banana, flag'; Pk. kayala, ${ }^{\circ} l \bar{l}, k \bar{e} l a,{ }^{\circ} l \bar{l}$ 'the banana plant', kayala 'its fruit'; K. kela 'fruit of the plantain'; S. kero 'Pandanus odoratissimus' keviro 'banana plant' < kētaka; Garh. kēlu 'plantain,' Ku.

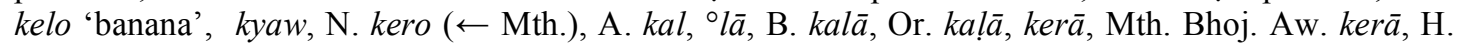

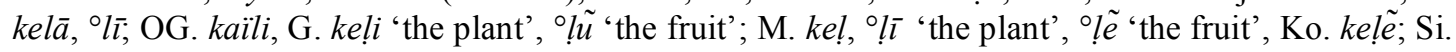
kehel, kesel) 'banana plant', keheliya 'banner'; --- with -ll-> S. kelo 'Pandanus odoratissimus'; P. kēlā, kellā 'banana'. Further: Mth. karari 'banana', Md. keyo (kēlek), kēl. -- See now Osada 2006: 158 sqq. 159 However, attested only from the Hellenistc period onward.

160 From Austroasiatic, see KEWA I 495 with literature. The use of areca with the betel leaf is derived from S.E. Asia, see Madhi 1998,

161 From AustroasAsiatic: J. Przyluski BSL xxiv 257.
} 
From China stem Panicum miliaceum and Setaria italica, ${ }^{162}$ while sorghum, pearl millet and finger millet came from Africa. Some of the earliest African crops are found in Gujarat in the Late Harappan period (2200-1700 BCE), ${ }^{163}$ while some of them had spread to the South by 1600-1500. This import will account for some of the loanwords for 'millet' in IA and Drav. that accompanied the spread of the plant.

On the other hand, as multiple evidence shows, names for different types of millet can be exchanged for more recently acquired crops and this occurs even for different species such as 'corn' (wheat) and maize. South Asia has many such examples. It remains unclear for the time being, therefore, which of the old Drav. terms for millets indicated which variety.

Krishnamurti (2003) lists only the Proto-Drav. words * $\bar{a} r /$ ar-ak, DEDR 812 (Tam. irāki, Kan. rāgi, Tel. érugu, etc.) and *kot-ə 2165 (?, not found in DEDR). However, Burrow/Emeneau (1984) list 46 items related to millet, some of which just refer to part of it, to grinding etc. The actual terms are listed below; their respective dates need to be investigated further.

DEDR $812 *$ ar/ar-ak seems to be related to $379 \mathrm{Ka}$. arike the Indian millet, Panicum italicum. ${ }^{164}$ There also is a vague similarity with DEDR 525 Ta. irunk $k$ great millet (Sorghum vulgare); irați Italian millet (Setaria italica), black Italian millet (Panicum indicum), Ma. irruñin a kind of maize. Cf. 812 Koḍ. Eri, and ProtoAustroasiatic * rkew, Munda runkub etc., Vedic vrīhi. ${ }^{165}$

Ultimately, given the early attestation of various millets, these words may be loan words that made it into the various Drav. languages at various times and from different substrates preceding the spread of Dravidian. ${ }^{166}$

§ 5.1.1 DEDR 1242 Ta. kampu, kampam-pul bulrush millet, Italian millet. Ma. kampu id.; kampam a grain; kamp-ari Holcus spicatus( < kampu 'bulrush millet' + ari 'millet' ?!); Ka. kambu, Te. kambu. DEDR compares Skt. kambü, ${ }^{167}$ for which cf. $\S 2.4 .3$ (discussion of kangu).

$\S$ 5.1.2. DEDR 2163 Ta. kural Italian millet, etc. ${ }^{168}$ Cf. the Munda words kuru, etc. (§ 4.1.5.)

§ 5.1.3. DEDR 286 Ta. cōlam, connnal maize, great millet, Sorghum vulgare, etc. 169

\footnotetext{
162 Fuller 2006, 2009: 5.

163 Fuller 2006, 2009: 8.

164 Further: hāraka, hāraku Paspalum scrobiculatum Lin., Te. āruka, āruga, ārike, āriga P. scrobiculatum (P. frumentaceum); āllu (pl.) P. scrobiculatum. Go. ārk Setaria italica; Pe. ārku (pl.) a species of millet; Kui ārka, Kuwi ārgu (pl. ārka) Panicum italicum.

165 Detailed discussion in Witzel 1999, Osada 1995.

166 For the probably oldest traceable substrate, Proto-Australian, see Blažek 2006.

167 Hem. Un 847 = kuruvinda Pennisetum typhoideum Rich. = Panicum spicatum Roxb. $=$ H. spicatus Linn., and many other synonyms). -- Note also: 1165 Ko. kank, kanuku 'stalk of the great millet;' 195 Pa. ayk a kind of grain called in Halbi kayg (Panicum italicum); cf. Turner, CDIAL, no. 2605; Ga. (S.2) aykil 'a kind of millet called in Te. korralu (Setaria italica; = Panicum italicum Linn.; 56 Ko. vatm 'millet, Panicum miliare.' To. potm 'millet,' kafotm sp. millet (ka- black). Ka. batta, bhatta 'paddy.'

168 Ko. koyl Setaria italica; korly. Ka. korale, korle 'a kind of millet, Panicum italicum Lin. Te. korralu (pl.); korra 'the cereal yielding korralu.' Pa. koyla P. italicum. Go. kōhalā, kohalā, kohala, ko ' la Panicum miliare; gorray ( $\mathrm{pl}$.), gor a (pl. - $\eta$ ), korra 'manḍeya corn,' Eleusine coracana. Konḍa koren ( $p l$.) 'a grain' (= Or. kāngu). Kui kueri 'millet.' S. italica Beauv. = P. italicum Linn.

169 Ma. cōlam, To. swḷm 'maize,' Ka. jōla ‘a generic name for several species of millet,' Koḍ. jḷa 'great millet,' Tu. jōla, Te. jonna, jonnalu, Kol. sonna (pl. sonnal), Nk. sonna juwari, Pa. jenna (pl. jennel) 'small maize, juwar,' Ga. jōnel $(\mathrm{j}=\mathrm{dz})$ 'maize,' jonnēl cholam 'millet,' Go. jonna 'jowar,
} 
$\S$ 5.1.4. DEDR 3265 Ta. tinai Italian millet, Setaria italica; wild Bermuda grass, Panicum burmanni ; little millet (=cāmai); paddy-field grass, $P$. fluitans, etc. ${ }^{170}$

§ 5.1.5. DEDR 3712 Ta. nuvanai black Italian millet, etc. ${ }^{171}$

$\S$ 5.1.6. DEDR $5260 \mathrm{Ta}$. varaku common millet, Paspalum scrobiculatum; poor man's millet, $P$. crusgalli. ${ }^{172}$

\section{$\S$ 5.2. RICE}

Rice has been discussed earlier as far as IA and Munda are concerned $(\S 2.3,4.1)$. As mentioned, Krishnamurti ${ }^{174}$ lists three reconstructed Proto-Drav. words for 'rice': (paddy) *kūl-i DEDR 1906, *nel 3743, *war-iñ 5265, and adds words for dry and wet fields $(2891,4337)$, transplanted seedlings 2919 , etc. He notes the relatively early attestation as a loanword in Greek oryza (however, only from Alexander's historians, c. 300 BCE onward), and derives it from Proto-Drav. *war-iñci, Tamil, Mal., Tel. wari, etc., (not from Tamil arisi $<*$ ariki; ${ }^{175} \mathrm{cf}$, , however, Austronesian *beras, Tibetan hbras and Skt. vrīhi $<*$ vrïjhi).

As a difference is always made in Asia between words designating cooked rice and uncooked rice (or rice still on the stalk), it is important to note that at least the literary languages of the South have words for 'cooked rice, thick porridge' $k \bar{u} z$ 1911, *amp-ali 174, and gruel *kañc-i 1104.

The three ancient, Proto-Drav. words for rice reconstructed by Krishnamurti are the following.

$\S 5.2 .1 * k \bar{u} l-i$ DEDR 1906, which is in fact found in some central Indian Drav. languages: Konḍa $k \bar{u} l i$ 'paddy' Pe. $k \bar{u} l i$, Manḍ. $k \bar{u} l i$, Kui $k \bar{u} d i$ 'grain, paddy, seed.' Kuwi $k \bar{u} l i$ 'paddy', and these are perhaps to be compared with Ta. kūlam 'grains, esp. of 18 kinds, viz. nel, pul,' etc. However, North Dravidian Br. xōlum wheat is loaned from Skt. godhūma.

$\S$ 5.2.2. *nel DEDR 3743: Ta. nel 'rice, paddy, grain of paddy,' etc. ${ }^{176}$

maize,' jona, jōnnang ‘jowar,' jonā 'maize,' jannā, jandra 'jowar', Kuwi kā'wa 'jōna millet.' Similar words in IA, see CDIAL 10434 yavanāla, see above. (Andropogon sorghum Brot. = Holcus sorghum Linn. $=$ S. vulgare Pers.).

170 Ma. tina 'P. italicum. ' Ko. ten 'ear (of any grain),' Ka. tene 'a spike, ear of corn;' tene-gida Italian millet, P. italicum.([S. italica Beauv. = P. italicum Linn.)

$171 \mathrm{Ka}$. navane, navani 'a small grain, the Italian millet or panic seed, Panicum italicum.'

172 Ma. varaku 'P. frumentaceum; a grass Panicum, ' Ka. baraga, baragu 'P. frumentaceum; Indian millet; a kind of hill grass of which writing pens are made.' Te. varaga, varuvu 'Panicum miliaceum.' DEDR compares Mar. barag 'millet, P. miliaceum,' Skt. varuka- 'a kind of inferior grain.' ( Paspalum scrobiculatum Linn. = P. frumentaceum Rottb.) . -- Cf. (v)ari 'rice', above $\S$ 5.2.3.

174 Krishnamurti 2003:9.

175 Krishnamurti 2003: 5.

176 Ma. nel 'rice (as growing), rice in the husk, paddy,' Ko. nel 'paddy, unhusked rice,' nel aky 'husked rice,' To. nes rice (in songs), neșišky rice (see ašky, s.v. 215 Ta. ari). Ka. nel, nellu 'paddy, rice in its husk, rice as growing, a grain of paddy,' Koḍ. nelli 'rice, paddy,' Te. nellūru n. pr. a town. 
§ 5.2.3 *war-iñc DEDR 5265: Ta. vari 'paddy,' etc. ${ }^{177}$ These words are similar to the S.E Asian ones and their history needs elucidation. ${ }^{178}$ Maybe the following word is connected: 5287 Ta. valci 'paddy, husked rice, boiled rice, food,' Ma. varru 'grain of boiled rice from which the water is strained off', Te. vadlu 'unhusked rice, paddy,' Kol. val 'grain of unhusked rice,' Nk. val 'paddy', valku ( $p l$.) 'paddy, rice.'

However, Burrow/Emeneau (1984) also discuss the following words.

$\S$ 5.2.4. DEDR 215 Ta. ari 'rice, paddy, ear of paddy;' arici 'rice without husk, any husked grain,' etc. ${ }^{179}$

$\S$ 5.2.5. DEDR 3614 Ta. navarai 'a kind of paddy;' nakarai 'a kind of rice,' etc. ${ }^{180}$ To be compared is Skt. niv āra 'wild rice' (CDIAL 7571, see $\S 2.3$.) This word is attested from a relatively early Vedic period onward, the Yajurveda Samhitās.

$\S$ 5.2.6. Some central Indian Drav. languages have an additional word: $D E D R 4639 \mathrm{Ga}$. $m$ âjik rice; manjig unhusked rice, etc. ${ }^{181}$

$\S$ 5.2.7. Finally, a few more designations for 'boiled rice' may be added from Burrow/Emeneau:

DEDR 4860 Ta. mitavai 'boiled rice, porridge, gruel, preparation of dhal;' miti 'food mixed with ghee;' vitavai 'boiled rice, gruel;' metukku 'boiled rice'; Te. meduku, metuku 'a grain of boiled rice; boiled rice'; Ga. metkul 'cooked rice' $(<\mathrm{Te}$.)

DEDR 3982 Ta. parukkai, porukku 'single grain of boiled rice'; perukkal 'rice'; poruku 'boiled rice,' etc. 182

DEDR 5186 Pe. lay 'boiled rice,' Manḍ. lay, Kuwi lahi; lāh'i boiled mandeya grain.

DEDR 2391 Ta. aval rice obtained from fried paddy by pestling it; avai (-pp-, -tt-) 'to pound in a mortar, crush, cuff, prod;'183 (see however $\S 3.1$.); the words are not

177 Ma. vari 'a wild-growing rice with rough beards,' Te. vari 'paddy,' Pa. verci, Ga. varsil, varcil, vars/varcil; vars piru '(rice) straw' (see 4225). Go. wanjī 'rice, both growing and in the grain,' vanjī 'paddy,' vanjī 'rice, seed,' venjī perek 'rice' (see 3982), vanji 'paddy.' -- Note Austronesian forms like wari, (Witzel 1999) and cf. 5287 Ta. valci.

178 Discussion in Witzel 1999, Southworth 2005.

179 Ma. ari 'grain of rice freed from chaff, seed, grain,' (Kauț.) arici 'rice,' Ko. aky 'grain of any grain food when husked,' To. ašky 'rice,' neșišky (cf. s.v. 3753 Ta. nel), Ka. akki 'rice deprived of its husk, grain that resembles rice,' Koḍ. akki 'husked rice,' Tu. ari 'rice freed from husk, any small grain,' akki 'rice, corn,' argi 'rice?'; Te. arise 'a sweetmeat made of rice, flour, and jaggery.' Cf. DEDR 3829 Ko. pack, To. počišky.-See discussion above $\S 5.2$.

180 Further: Ma. navira, naviri, nakara 'a rice that ripens within two or three months,' navara, Paspalum frumentaceum (?). Tu. navara 'a kind of grain,' navare 'a kind of rice,' Te. nivari, nivvari 'Oryza.'

181 nongre manjik 'broken pieces of rice after pounding,' Konḍa manzi (pl. -k) 'husked rice,' Pe. manji (cf. 3982 preyi), Kuwi manji, 'raw rice, rice without husk, husked rice, a grain of rice; manjin 'husked rice,' Kur. mãnjī 'seed in general.' Cf. Go. wanjī, s.v. 5265 Ta. vari

182 Te. prālu 'rice,' Nk. perku 'husked rice,' Pa. peruk (pl. perkul), Go. parēe 'husked rice,' kuṭki, etc.; parek 'husked (of rice),' paraik, paraik, perek 'husked rice,' pere, pariku 'rice,' parem (pl. parek) 'grain (of rice, etc.),' Konḍa per(u) (pl. perku) 'husked rice,' Pe. preyi, Manḍ. Preyi, Kui prāu 'rice, husked paddy,' prāma 'a grain of boiled rice,' kōruvrau, kōruvau 'flaked rice.'

183 avaiyal well-husked rice,' Ma. avil 'rice bruised and dried,' avekka 'to beat rice,' aval 'flattened rice obtained from paddy by pestling it,' Ko. kac av- (avt-) 'to pestle (millet) second time,' aky av(avt-) 'to pestle (millet) third time,' To. af- (aft-) 'to pound with light strokes,' ofil 'puffed rice,' Ka. aval 'pound, beat, pounding, beating in a mortar,' (also aval-akki) 'rice bruised and crushed,' Koḍ. avl- 
connected by Burrow-Emeneau) with rice but rather, DEDR 268 with boiling: Ta. avi ($v-,-n t-)$ 'to be boiled, cooked by boiling or steaming, swelter; (-pp-, -tt-) (which includes boiling rice).

\section{$\S$ 5.3. BARLEY}

Not unsurprisingly, this plant is attested only sparsely, at high altitude levels of the Nilgiris, in Toda and in Kota. DEDR 1106 Ko. kaj barley. To. koj (cf. Pkt. gajja). It is not listed in Krishnamurti 2003.

\section{$\S$ 5.4. WHEAT}

As discussed above ( $§ 1.6)$, the Drav. word for 'wheat' (*gōdi) arrived in S. Asia, along with the plant, before the Indus period via the southern Iranian route (Elam - Tepe Yahya - Bampür- Sindh). It has resulted in the reconstructed southern Indus term ('Meluhhan') ${ }^{*} g \bar{o} d / t$-, which is retained in Drav. ${ }^{*} g \bar{o} d i .{ }^{184}$ The pre-Iranian *gantum must have become *go-tum or *go-dum in Sindh. Just as in IA, the Drav. word reflects a popular etymology ${ }^{185}$ of the unfamiliar plant: *godum: from *kō-tumpai, 'low red plant"186 in PDrav. stage 3, at c. 1000 BCE. ${ }^{187}$ Significantly, there are no Proto-Drav. or old, indigenous words for 'wheat' in Dravidian - they could not be as the plant as been introduced fairly late in linguistic history.

\section{$\S 5.5$. GRAIN}

A general word for 'grain' (or 'kernel') DEDR 4153 is found in some languages, such as central Indian Gondi and Parji and Malayalam in the South. It is not listed in Krishnamurti 2003.

\section{$\S$ 6. Summary and Outlook}

We can detect several ancient centers of food production in India: the west (Indus civilization, including Haryana and W. Gujarat), the Gangetic plains and the South, each one with its own peculiar package of plants and domestic animals. The linguistic data, gleaned for the most ancient texts (Veda, Sangam) agree with this scenario. They actually

$a k k i$ 'rice fried and each grain pounded flat,' Tu. abepuni, abeyuni, abeccuni 'to beat or pound rice,' Kol. cavli 'mortar,' Nk. Savli, Nk. Savli, Pa. cavil, cavkol (pl. cav-kocil) 'pestle,' Ga. savul 'mortar,' savkol 'pestle,' savvul 'mortar,' savkōl 'pestle'? Go. sahkī, sāhkī, sahki, cahki, hahki, ahki, a 'ki, ahk (or with 2799 Konḍa sonki, Pe. henki). Cf. CDIAL 4749 *cāmala, cāvala 'husked rice.'

184 Kan. gōdi, Tam. kōti, DEDR 1906; cf. also Kinḍa kūli 'paddy’ DEDR 1906.

185 Cf. Southworth, F. C. Linguistic Archaeology of South Asia. London and New York: Routledge 2005: 80, 198. However, wheat is found in S. India after 2200 BCE. The various Elamite, Sumerian, etc. loans into Drav. will have to be compared.

186 As reconstructed by Southworth 1988: 658, 660.

187 See DEDR 3334: Tam. tumpai etc. 'nettle, weed.' The exact development from *tumpai $>-d i$ is not clear; at this late date kōtumpai could even be based on Ved. godhūma. 
further improve and refine the picture, as they allow to go well beyond the ancient texts and access the earlier periods preceding them.

Behind the Late Bronze Age data of the Rgveda we can thus detect an ancient population that already possessed its own indigenous agricultural terms. We can connect this substrate with the preceding agricultural communities of the Indus Civilization (2600-1900), and even with its predecessors (c. 6000-2600 BCE), both of which had adopted the typical W. Asian wheat/cattle/caprid package.

The same procedure applies to the Gangetic plains as depicted in the later Vedic texts (c. 1000-500 BCE), and as still indicated by modern IA languages such as Hindi, etc. An earlier Gangetic substrate emerges that has peculiar agricultural terms corresponding to its specialized rice/buffalo package (c. 3000/2500 BCE).

The case for the South is again similar: the Dravidian languages indicate a southern package of food production (millet/cattle), especially when making use of reconstructed Proto-Dravidian. This early form differs considerably from the data of the later, iron-age stage of the southernmost languages (Tamil-Malayalam), with developed millet/rice agriculture and saw emerging state formation.

As is obvious, much of the relevant data are still obscured by the evidence hidden in the little studied substrates of the IA, Drav. and Munda languages. Much more work by linguists has to be done to see progress in the evaluation of the culture of these early periods. For a beginning, one may consult the online substrate dictionary (in progress), SARVA.

Second, many details need to be elucidated through close cooperation between linguists and archaeo-botanists. Unfortunately, strict procedures in dealing with flora (and fauna) in archaeological excavations in the subcontinent have been employed only fairly recently, and earlier reports cannot be trusted with regard to the (scanty) collections and identifications of plant and animal remains. We need substantive and representative regional collections for comparisons ${ }^{188}$ in order to achieve substantial progress.

Remembering such great early summaries as the $17^{\text {th }}$ century Hortus Malabaricus for Kerala, or the --still useful ones - such as Brandis' on Indian trees, ${ }^{189}$ we also have to compare other early textual materials. Much is still hidden in the largely unpublished and untranslated texts on Vṛkṣa Āyurveda, which actually deal not just with trees but also with agriculture in general. This includes, for example, such unexpected methods of fertilization of trees by fish residue. Some of these Ayurveda texts contain elaborate pictures of the plants described. I have seen one such beautifully illustrated book in private possession (Ayurveda Society of Naradevi, Kathmandu) that had detailed descriptions in a multitude of Indian languages, ${ }^{190}$ or I have once come across a collation of agricultural data of many hundreds of Sanskrit pages, made for the Union Government, already in 1979.

Third, we urgently need regional surveys of smaller languages and dialects, especially of remnant languages like Kusunda, Tharu, Bhili, Nihali, Toda (and also of Andamanese, Shompen, Vedda) as to gain a clearer picture of the early stages of food production in India, -- especially for areas that do not have old literatures (such as Central India). This

\footnotetext{
188 Meadow 1998, 12-21, Meadow and Patel 2003.

189 Reede tot Drakestein 2003; Brandis 1906.

190 Or, for example the illustrated manuscript of the Kitab al-Hashaish, in the Khuda Baksh Oriental Public Library, Patna, no. HL 2189, see: Vijñānavidhi. Manuscript Treasures of India. New Delhi: National Mission for Mansucripts 2007: 62 (in Arabic, and occasionally, in Greek).
} 
has then to be expanded by the study of substrate words in the literary languages and in the extant vocabularies of all Indian languages - a task barely begun outside IA. Otherwise, we remain boxed in, for our earliest data, between those from the extreme Northwest (Rgveda) and the extreme South (Sangam), at 1000 and 200 BCE respectively, and have to extrapolate for the rest of the subcontinent.

I conclude, therefore, with an appeal to botanists ${ }^{191}$ (and zoologists) ${ }^{192}$ to join forces with archaeologists, geneticists, linguists and textual scholars to exchange data and discuss them in collaborative fashion. ${ }^{193}$ Only then real progress will be possible.

191 See however, already the paper, 40 years ago, 1967-68, by Vishnu Mittre, which is characterized as: "Vishnu Mittre looks into dating mechanism, environmental archaeology, and palaeontology in relation to archaeology and recommends a closer collaboration."

192 Not treated here, but similarly promising.

193 Such as at our yearly Harvard Round Tables:

http://www.people.fas.harvard.edu/ witzel/ROUND\%20TABLES-2007.htm and later ones (20082009) at the same website. 
Abbreviations for common language names

(listed in the etymological dictionaries in this order)

\begin{tabular}{llll}
\multicolumn{2}{l}{ Indo-Aryan } & \multicolumn{2}{l}{ Dravidian } \\
$<$ Nur. & Nuristani> & Ta & Tamil \\
Dard. & Dardic & Ma & Malayalam \\
Gy & Gypsy & Te & Telugu \\
K & Kashmiri & Ko & Kota \\
S & Sindhi & To & Toda \\
L & Lahnda & Ka & Kanada \\
P & Panjabi & Kod & Kodagu \\
WPah & W. Pahari & Tu & Tulu \\
Garh & Gahrwali & Kol & Kolami \\
Ku & Kumauni & Nk & Naike \\
N & Nepali & Pa & Parji \\
A & Assamese & Ga & Gadba \\
B & Bengal & Go & Gondi \\
Or & Oriya & Kor & Koraga \\
Bi & Bihari & Kur & Kurukh (Oraon) \\
Mth & Maithili & Malt & Malto \\
Bhoj & Bhojpuri & Br & Brahui \\
Aw & Awadhi & & \\
H & Hindi & & \\
Marw & Marwari & & \\
G & Gujarati & & \\
M & Marathi & & \\
Ko & Konkani & & \\
Si & Singhalese & &
\end{tabular}

Other common abbreviations

AV Atharvaveda Saṃitā

CDIAL Turner, Comparative Dictionary of the IA languages

DEDR Burrow and Emeneau, Dravidian etymological Dictionary

Drav. Dravidian

EJVS Electronic Journal of Vedic Studies

EWA Mayrhofer, Etymologisches Wörterbich des Altindoarischen

IE Indo-European

IA Indo-Aryan

IIJ Indo-Iranian Journal

IIr Indo-Iranian

KS Katha Samhitā of the YV

lex. = found in dictionaries only

MIA Middle Indo-Aryan

Mbh. Mahābhārata

MS Maitrāyani Saṃhitā of the YV

NIA New Indo-Aryan

O. old

Pa. Pali

PIE Proto-Indo-European

Pkt. Prakrit

R(ām). Rāmāyaṇa 
RV Rgveda-Samhita

Skt. Sanskrit

Suśr. Suśruta

TS Taittirīya Saṃhitā of the YV

VS Vàjasaneyi Saṃhitā of the YV

YV Yajurveda

Bibliography Plant names

Allchin, F.R. and B. Allchin. The rise of Civilisation in India and Pakistan. Cambridge Univ. Press 1982

Allchin, F. R. The Archaeology of Early Historic South Asia. The Emergence of Cities and States. With Contributions from George Erdosy, R. A. E. Coningham, D. K. Chakrabarti and Bridget Allchin. Cambridge: Cambridge University Press 1995

Allchin, F. R. and N. Hammond, The Archaeology of Afghanistan from the earliest times to the Timurid period. London, New York: Academic Press 1978

Anderson, G. D. S. (ed.). The Munda Languages. London and New York: Routledge 2008

Beekes, R.S.P. Comparative Indo-European linguistics: an introduction, Amsterdam/Philadelphia: J. Benjamins Pub. 1995

Bellwood, P. and C. Renfrew (eds.) Examining the farming/language dispersal hypothesis. Cambridge: McDonald Institute for Archaeologcial Research/Oxbox Books. University of Cambridge 2002

Benedict, P.K. Sino-Tibetan. A conspectus. Cambridge 1972

Berger, H. Die Burušaski-Lehnwörter in der Zigeunersprache. IIJ 3, 1959, 17- 43

Berger, H. Die Burushaski-Sprache von Hunza und Nager. Wiesbaden: Harrassowitz 1998

Blažek, V. Was there Australian Substratum in Dravidian? Mother Tongue XI, 2006, 275-285.

Brandis, D. Indian trees : an account of trees, shrubs, woody climbers, bamboos, and palms indigenous or commonly cultivated in the British Indian Empire; assisted by Indian foresters. London: A.

Constable \& co., ltd 1906

Burrow, T. and M.B. Emeneau. A Dravidian Etymological Dictionary. Second Edition. Oxford: Clarendon Press 1984

Cardona, G. The Indo-Aryan languages, edited by George Cardona and Dhanesh Jain, London; New York: Routledge 2003

Donegan, P. and D. Stampe, Rhythm and the Holistic Organization of Language Structure. Based on the version in: Papers from the Parasession on the Interplay of Phonology, Morphology, and Syntax, ed. John F. Richardson, Mitchell Marks, and Amy Chukerman. Chicago: Chicago Linguistic Society, 1983,: 337-353. http://ling.1ll.hawaii.edu/austroasiatic/AA/rhythm1983.pdf

Driem, G. van. The prehistory of Tibeto-Burmese in the light of emergent population genetic studies. Mother Tongue XI, 2006, 160- 211 
Ehret, C. Language Family Expansions: Broadening our Understandings of Cause from an African Perspective, in: Bellwood, P. and Renfrew, C. (eds.) Examining the farming/language dispersal hypothesis. Cambridge, UK: McDonald Institute for Archaeological Research, University of Cambridge; Oxford; Oakville, CT. Distributed by Oxbow Books 2002: 163-176

Elfenbein, J.H. A periplous of the 'Brahui problem'. Studia Iranica 16, 1987, 215-233

Fuller, D. Q. Silence before sedentism and the advent of cash-crops. A status report on early agriculture in South Asia from plant domestication to the development of political economies (with an excurrsus on the problem of semantic shift among millets and rice). In: T. Osada (ed.). Proceedings of the PreSymposium of RHIN and 7th ESCA Harvard-Kyoto Round Table. Published by the Research Institute for Humanity and Nature (RHIN), Kyoto 2006: 175-213.

Fuller, D. Q. Agricultural origins and frontiers in South Asia: a working hypothesis. Journal of Wold Prehistory 20, 2006a, 1-86

Fuller, D.Q. Framing a Middle Asian corridor of crops exchange and agricultural innovation. In: 13th Harvard University Round Table. Ethnogenesis of South and Central Asia (ESCA), Kyoto session. Kyoto: Research Institute for Humanity and Nature (RHIN), Kyoto, Japan, 30-31 May 2009, p. 3-11

Fuller, D.Q. The Archaeobotanist, 25 June 2009, http://Archaeobotanist.blogspot.com/indianarchaeology-watch-lahuradewa.html

Fuller, D. Q. The Archaeobotanist 25 Aug 2009; http://archaeobotanist.blogspot.com/2009/08/milletsand-mistakes.html

Glover, L.C. and Hingham, C.F.W. New evidence for early rice cultivation in South, Southeast and East Asia. In: D. R. Harris (ed.), The origins and spread of agriculture and pastoralism in Eurasia. London: UCL Press 1996: 413-441

Hingham, C. Languages and Farming Dispersals: Austroasiatic Languages and Rice Cultivation, In: Bellwood and Renfrew 2002, 223-232

Hock, H.H. Out of India? The linguistic evidence. In: Bronkhorst, J. \& M. Deshpande (eds.), Aryan and Non-Aryan in South Asia. Evidence, Interpretation and Ideology. Harvard Oriental Series. Opera Minora, vol. 3. Cambridge 1999, 1-18

Karlgren, B. Analytical Dictionary of Chinese and Sino-Japanese. Paris 1923

Kenoyer, J. M. Ancient Cities of the Indus Valley Civilization. Oxford: Oxford University Press/American Institute of Pakistan Studies 1998

Krishnamurti, Bh. The Dravidian Languages. Cambridge: Cambridge University Press 2003.

Kuiper, F.B.J. Rigvedic loan-words. In: O. Spies (ed.) Studia Indologica. Festschrift für Willibald Kirfel zur Vollendung seines 70. Lebensjahres, Bonn: Orientalisches Seminar 1955

Kuiper, F.B.J. Aryans in the Rigveda, Amsterdam-Atlanta: Rodopi 1991

B.B. Lal, The Homeland of Indo-European Languages and Culture: Some Thoughts. Purattattva 32 , 2001-2, 1-4

Lubotsky, A. The Indo-Iranian Substratum, in: Early Contacts betwen Uralic and Indo-European: Linguistic and Archaeological Considerations, ed. Chr. Carpelan, A.Parpola, P.Koskikallio. Helsinki, SuomalaisUgrilainen Seura 2001: 301-317

Mahdi, W. Linguistic data on transmission of Southeast Asian cultigens to India and Sri Lanka, Blench, R. and M. Spriggs (eds.) Archaeology and Language II. Correlating archaeological and linguistic hypotheses. $1998: 390-415$

J.P. Mallory \& Adams, D.Q., Encyclopedia of Indo-European culture, London; Chicago: Fitzroy Dearborn 199 
Masica, C P. Aryan and Non-Aryan Elements in North Indian Agriculture. In: M. M. Deshpande and P. E. Hook (eds.), Aryan and Non-Aryan in India (Ann Arbor : Center for South and Southeast Asian Studies), 1979: 55-151

Mayrhofer, M. Kurzgefasstes etymologisches Wörterbuch des Altindischen. Heidelberg 1956-1976.

Mayrhofer, M. Etymologisches Wörterbuch des Altindoarischen. Vol. I-IV Heidelberg: Winter 19862000

Meadow, R. H. Pre- and proto-historic agricultural and pastoral transformations in northwestern South Asia. Review of Archaeology. The transition to agriculture in the Old World (Special Issue ed. by Ofer Bar-Yosef) 19, 1998, 12-21

Meadow, Richard H. and Ajita K. Patel. Prehistoric pastoralism in northwestern South Asia from the Neolithic through the Harappan period. Chapter 3 in Steven A. Weber and William R. Belcher (eds.) Indus Ethnobiology: New Perspectives from the Field. Latham, MD: Lexington Books 2003: 65-93

Mundlay, A. Who are the Nihals? What Do They Speak? Mother Tongue (Boston: Association for the Study of Language in Prehistory), Vol. II, p. 5-40

Osada, T. The agricultural Vocabulary in Proto-Munda. In: The Rice and Food Culture of Munda in Eastern India: An Ethnolinguistic Study.[in Japanase] Kyoto 1995: 143-157

Osada, T. (ed.). Proceedings of the Pre-Symposium of RHIN and 7th ESCA Harvard-Kyoto Round Table. Published by the Research Institute for Humanity and Nature (RHIN), Kyoto 2006

Osada, T. How many Pro-Munda words in Sanskrit? - with special reference to agricultural vocabulary. In : Osada 2006: 151-174

Parpola, A. Deciphering the Indus script. Cambridge: Cambridge University Press 1994.

Pinnow, H.J. Versuch einer historischen Lautlehre der Kharia-Sprache, Wiesbaden 1959

Ramachandran, Puthusseri and K. Nachimuthu (eds.) Perspectives in Place Name Studies: Proceedings of the National Seminar on South Indian Place Names, Held at Trivandrum on 21-23 June 1985. A Festschrift to Prof. V.I. Subramoniam, On His Sixtieth Birth Day. Trivandrum: Place Name Society 1987

Randhawa, M. S. A history of agriculture in India. New Delhi : Indian Council of Agricultural Research 1980-1986

Rau, W. The earliest literary evidence for permanrnt Vedic settlements. In: In: Inside the Texts, Beyond the Texts. New Approaches to the Study of the Vedas. (M. Witzel, ed.) Harvard Oriental Series. Opera Minora, vol. 2. Cambridge 1997, 202-206.

Reede tot Drakestein, Hendrik van. Hortus malabaricus (English version: Malabar Garden) with annotations and modern botanical nomenclature by K.S. Manilal. Thiruvananthapuram : University of Kerala, 2003

Sato Y.-I. Rice and the Indus Civilization. In: Osada 2006: 213-214.

Sato, Y.-I. of crops: what is common and what is different? - Fudo and agriculture. In: T. Osada (ed.). Proceedings of the Pre-Symposium of RHIN and 7th ESCA Harvard-Kyoto Round Table. Published by the Research Institute for Humanity and Nature (RHIN), Kyoto 2006: 73- 78

Southworth, F.C. Ancient economic plants of South Asia: linguistic archaeology and early agriculture. In: Languages and Cultures. Studies in Honor of Edgar C. Polomé. M.A. Jazayery and W. Winter (eds.), Berlin/New York : Mouton de Gruyter 1988, 659-668 
Southworth, F.C. Reconstructing social context from language: Indo-Aryan and Draviian prehistory. In: Erdosy, G. (ed.) (1995) The Indo-Aryans of Ancient South Asia. (Indian Philology and South Asian Studies, A. Wezler and M. Witzel (eds.), vol. 1), Berlin/New York: de Gruyter 1995: 258-277

Southworth, F.C. Linguistic Archaeology of South Asia. London and New York: Routledge 2005

Southworth, F.C. New light on three South Asian language families. Mother Tongue XI, 2006, 124159.

Southworth, F.C., D. Stampe, M. Witzel, SARVA substrate dictionary, http://www.aa.tufs.ac.jp/sarva/entrance.html;

Stampe, D. Online Munda dictionaries: http://ling.1ll.hawaii.edu/austroasiatic cf. http://www.aa.tufs.ac.jp/sarva/materials_frame.html

Szemerenyi, O. Introduction to Indo-European linguistics. Oxford : Clarendon Press / New York : Oxford University Press 1996.

Tewari, R. et al., Early Farming at Lahuradewa, International Seminar on the First Farmers in Global Perspective, Lucknow 18-20 Jan. 2006, Prāgdhārā 18 (2009).

Turner, R. L. A comparative Dictionary of the Indo-Aryan Languages. London 1966

Vijñānavidhi. Manuscript Treasures of India. New Delhi: National Mission for Manuscripts 2007

Vishnu-Mittre, Birbal Sahni Institute of Palaeobotany, Lucknow: Inter-relations between Archaeology and Plant Sciences, Puratattva 1, 1967-68, 4-14

Watters, D. Notes on Kusunda grammar (a language isolate of Nepal). Kathmandu: National Foundation for the Development of Indigenous Nationalities 2005

Wiczak, K.T. Indoeuropejskie nazwy zbóz. Łódz: Wydawnictwo Uniwersytetu Łódzkiego 2003

Witzel, M. Nepalese Hydronomy: Towards a history of settlement in the Himalayas. Proceedings of the Franco-German Conference at Arc-et-Senans, June 1990. Paris 1993: 217-266

Witzel, M. Early Sources for South Asian Substrate Languages. Mother Tongue (extra number): 1-70, Boston 1999; cf. "Substrate Languages in Old Indo-Aryan (R.gvedic, Middle and Late Vedic)," Electronic Journal of Vedic Studies Vol. 5-1: 1-67. Available at http://ejvs.laurasianacademy.com /issues.html

Witzel, M. The Development of the Vedic Canon and its Schools: The Social and Political Milieu. In: Inside the Texts, Beyond the Texts. New Approaches to the Study of the Vedas. (M. Witzel, ed.) Harvard Oriental Series. Opera Minora, vol. 2. Cambridge 1997, 257345. http://www.people.fas.harvard.edu/ witzel/canon.pdf.

Witzel, M. Autochthonous Aryans? The Evidence from Old Indian and Iranian Texts. EJVS 7-3, 2001, http://www.people.fas.harvard.edu/\%7Ewitzel/EJVS-7-3.pdf.

Witzel, M. Linguistic Evidence for Cultural Exchange in Prehistoric Western Central Asia. Philadelphia: Sino-Platonic Papers 129, Dec. 2003

Witzel, M. Central Asian Roots and Acculturation in South Asia: Linguistic and Archaeological Evidence from Western Central Asia, the Hindukush and Northwestern South Asia for Early IndoAryan Language and Religion. In: T. Osada (ed.) Linguistics, Archaeology and the Human Past. Kyoto: Indus Project, Research Institute for Humanity and Nature 2004, 87-211. Reprinted by Manohar, Delhi 
Witzel, M. Indocentrism: Autochthonous visions of ancient India. In: The Indo-Aryan controversy : evidence and inference in Indian history / edited by Edwin F. Bryant and Laurie L. Patton. London ; New York : Routledge 2005

Witzel, M. South Asian agricultural vocabulary. In: T. Osada (ed.). Proceedings of the Pre-Symposium of RHIN and 7th ESCA Harvard-Kyoto Round Table. Published by the Research Institute for Humanity and Nature (RHIN), Kyoto 2006: 96-120

Zide, A. and N.H. Zide, Semantic reconstruction in proto-Munda cultural vocabulary. Indian Linguistics 34, 1973, 1-24

Zvelebil, K. Comparative Dravidian Phonology, The Hague 1970

Zvelebil, K. Dravidian Linguistics: an Introduction. Pondicherry: Pondicherry Institute of Linguistics and Culture 1990

$* * * * * * * * * * * * * * * * *$

\section{Note on Appendix I}

The appendix contains a list of the oldest attested words for Indian agricultural plants, as found in the Vedas (c. 1500-500 BCE). The list is arranged in a twofold way: (1) area of origin of the plant in question; (2) inside these groups, according to age of attestation. We have to distinguish 5 levels (Witzel 1997): 1.1. Rgveda - 1.2. Mantra texts (Atharvaveda, Yajurveda) - 1.3. Yajurveda Saṃitā prose texts (MS, KS, TS) -- 1.4. Brāhmaṇa texts proper, including earliest Upaniṣads and Āranyakas -- 1.5. Late Vedic (Sūtras); -- post-Vedic, in other Old Indo-Aryan OIA) texts: Epics, Middle Indo-Aryan (MIA), Classical Sanskrit, New Indo-Aryan (NIA).

\begin{tabular}{|c|c|c|c|c|c|}
\hline $\begin{array}{l}\text { English term } \\
\text { Geographic origin } \\
\text { of plant }\end{array}$ & $\begin{array}{l}\text { Old Indo- } \\
\text { Aryan term }\end{array}$ & $\begin{array}{l}\text { Attestation } \\
\text { level of texts: } \\
1.1-5 \text {, or post- } \\
\text { Vedic; area or } \\
\text { composition }\end{array}$ & $\begin{array}{l}\text { Origin: } \\
\text { Language } \\
\text { family or } \\
\text { individual } \\
\text { Language }\end{array}$ & Comments & $\begin{array}{l}\text { Discus } \\
\text { Mayrt } \\
\text { EWAi } \\
1986-\end{array}$ \\
\hline $\begin{array}{l}\text { SW ASIAN } \\
\text { Origin }\end{array}$ & & & & & \\
\hline$\overline{\text { Barley }}$ & yáva & $\begin{array}{l}1.1=\mathrm{RV}: \\
\text { Greater } \\
\text { Panjab }\end{array}$ & $\begin{array}{l}\text { Indo-Eur. } \\
\text { Gr. zeiai, Lith. } \\
\text { javai, Hitt. ewa }\end{array}$ & & $\overline{\overline{\text { II } 405}}$ \\
\hline$\overline{\text { Plough }}$ & lấngula & $\overline{\overline{1.1}}$ & $\begin{array}{l}\text { Munda or N.E. } \\
\text { (Witzel 1999) }\end{array}$ & $\begin{array}{l}\text { For Near } \\
\text { Eastern con- } \\
\text { nections, see } \\
\text { Blažek \& } \\
\text { Boisson 1991) } \\
\end{array}$ & $\begin{array}{l}\overline{\text { I } 477} \\
\text { clear, }\end{array}$ \\
\hline$\overline{\text { To sow }}$ & vap 'scatter' & $\overline{1.1}$ & $\begin{array}{l}\text { IIr. (O. Avest . } \\
\text { vi-uuap ); cf. }\end{array}$ & & $\begin{array}{l}\text { EWA } \\
504\end{array}$ \\
\hline
\end{tabular}




\begin{tabular}{|c|c|c|c|c|c|}
\hline $\begin{array}{l}\text { To plough } \\
\text { furrow }\end{array}$ & $\begin{array}{l}\text { (yavam) krṣ } \\
\text { 'to plough } \\
\text { ([for] grain)' } \\
\text { *sā/sī // sîtā } \\
\text { 'furrow' }\end{array}$ & 1.1 & $\begin{array}{l}\text { Hitt. huuapp? } \\
\text { IIr.: Avest. } \\
\text { yao-karšti , } \\
\text { etc., } \\
\text { yauunanam } \\
\text { karš; < IE } \\
\text { *kwels } \\
\text { IA *sā/saH? < } \\
\text { *seh 'throw'? } \\
\text { EWA II 725 } \\
\text { (sāyaka 'a } \\
\text { thrown object, } \\
\text { arrow'; cf. IE } \\
\text { *seh }(y) \text { 'to } \\
\text { sow' }\end{array}$ & $\begin{array}{l}\text { Cf. also sītā } \\
\text { 'furrow'; EWA } \\
\text { II } 732\end{array}$ & $\begin{array}{l}\text { EWA } \\
\\
\text { EWA } \\
731\end{array}$ \\
\hline & & & & & \\
\hline$\overline{\text { Wheat }}$ & godhû́ma & $\begin{array}{l}1.2 \text { AV+ } \\
\text { KS, TS } \\
\text { Central } \\
\text { northern } \\
\text { India; } \\
\text { (E.Panjab: } \\
\text { KS) }\end{array}$ & $\begin{array}{l}\text { Loan < } \\
\text { Near East, via } \\
\text { N. Iran } \\
\text { (Witzel 1999) }\end{array}$ & $\begin{array}{l}\text { Iranian (Avest.) } \\
\text { gantuma < Hitt. } \\
\text { kant, Egpt. xnd } \\
\vdots \\
\text { influenced } \\
\text { by *Pre-Drav. } \\
\text { *go- (cf. } \\
\text { Caucas. } \\
\text { * ghomu) }\end{array}$ & $\begin{array}{l}\text { I 499: } \\
\text { foreig } \\
\text { word; } \\
\text { popul: } \\
\text { etymo } \\
\text { ('cow } \\
\text { smokt }\end{array}$ \\
\hline & & & & & \\
\hline $\begin{array}{l}\text { Lentil, Lens } \\
\text { culinaris Med } \\
\end{array}$ & $\begin{array}{l}\text { masúra } \\
\text { másura }\end{array}$ & $\begin{array}{l}1.2 / 3 \mathrm{KS}, \\
\mathrm{TS} \text { (U.P.) } \\
\end{array}$ & $\overline{\text { Local word? }}$ & & $\begin{array}{l}\overline{\text { II 335 }} \\
\text { Uncle } \\
\end{array}$ \\
\hline Flax / lin seed & $\begin{array}{l}\text { atasá } \\
\text { brushwood; } \\
\text { atasī lin seed } \\
\end{array}$ & $\begin{array}{l}1.1 \\
\text { Suśruta }\end{array}$ & $\begin{array}{l}\text { Meanings un- } \\
\text { clear in RV }\end{array}$ & & $\begin{array}{l}\text { I57 } \\
\text { Uncle }\end{array}$ \\
\hline S. ASIAN origin & & & & & \\
\hline Rice & Vrīhí & $\begin{array}{l}1.2 \mathrm{AV} / \mathrm{PS} \\
\text { (in U.P./ } \\
\text { Haryana \& } \\
\text { Delhi) }\end{array}$ & $\begin{array}{l}\text { Local? -- see } \\
\text { Witzel 1999: } \\
<* \text { vrijhi; <> } \\
\text { Drav. (v)ari(ki), } \\
\text { variñci etc.; > } \\
\text { Greek oryza }\end{array}$ & $\begin{array}{l}\text { Cf. Jpn. uruchi; } \\
\text { Austrones. } \\
\text { (Taiwan) } \text { - }^{-} \\
\text {bəraə, vəras } \\
\text { etc.; Munda } \\
\text { *ərig > Drav. } \\
\text { vari- } \\
\end{array}$ & $\begin{array}{l}\text { II } 597 \\
\text { MPers } \\
\text { Pashtc } \\
\text { (pl.), }\end{array}$ \\
\hline$\overline{\overline{\text { Rice }}}$ & $\begin{array}{l}\text { s̄āli PS ; } \\
\text { sāri- AV }\end{array}$ & $\begin{array}{l}1.2 \text { AV,PS } \\
\text { C.N.India }\end{array}$ & $\begin{array}{l}\text { Benedict, Con- } \\
\text { spectus } 28, \#\end{array}$ & $\begin{array}{l}<\text { Tibeto- } \\
\text { Burmese ?? }\end{array}$ & II 632 \\
\hline
\end{tabular}




\begin{tabular}{|c|c|c|c|c|c|}
\hline & & & $\begin{array}{l}66 \\
\text { any conn. with } \\
\text { cāmala? }\end{array}$ & & \multirow{3}{*}{$\begin{array}{l}\text { II } 361 \\
\text { clear ; } \\
409 \text { b }\end{array}$} \\
\hline $\begin{array}{l}\text { Mung: Vigna } \\
\text { radiata }\end{array}$ & \multirow[t]{2}{*}{ " mudgá } & \multirow[t]{2}{*}{$\begin{array}{l}1.2 \mathrm{YV} \\
\text { N.India }\end{array}$} & CDIAL 10198 & \multirow[t]{2}{*}{$\begin{array}{l}\text { Cf. RV name: } \\
\text { Mudga-la 1.1.: } \\
\end{array}$} & \\
\hline & & & Local & & \\
\hline $\begin{array}{l}\text { Phaseolus mungo } \\
\text { L. var. radiatus = } \\
\text { Phaseolus } \\
\text { Roxburghii } \\
\end{array}$ & má́ṣa & $\begin{array}{l}1.2 \mathrm{AV} \\
\text { C.N.India }\end{array}$ & $\begin{array}{l}\overline{\text { CDIAL } 10097} \\
\text { Local }\end{array}$ & $\begin{array}{l}\text { Cf. MPers. } \\
\text { māš; NE: } \\
\text { Shughni } \max \end{array}$ & $\begin{array}{l}\overline{\text { II } 352} \\
\text { proble }\end{array}$ \\
\hline $\begin{array}{l}\text { Dolichos biflorus } \\
\text { L., a twining vine } \\
\end{array}$ & "khalá-kula & $\begin{array}{l}1.4 \text { Up. } \\
1.5 \text { Kauśs } \\
\text { N. India } \\
\end{array}$ & $\overline{\overline{\text { Local? }}}$ & $\begin{array}{l}\text { Cf.Tam. kol; } \\
\text { Parji pl. kol-kul } \\
\end{array}$ & $\overline{\overline{\mathrm{I} 449}}$ \\
\hline $\begin{array}{l}\text { chaff, straw } \\
\text { (fog) }\end{array}$ & $\begin{array}{l}\text { busa } \\
\text { (busá) }\end{array}$ & $\begin{array}{l}1.5 \text { KauśS } \\
\text { 1.1. RV } 10\end{array}$ & $\begin{array}{l}\text { Local; non-IA } \\
\text {-s- after -u- }\end{array}$ & & $\begin{array}{l}\text { II 231 } \\
\text { uncert }\end{array}$ \\
\hline $\begin{array}{l}\text { Cotton } \\
\text { (Gossypium sp.) }\end{array}$ & $\begin{array}{l}\text { Ved.*karpāsa } \\
\text { kārpāsa } \\
\text { 'made of } \\
\text { cotton' }\end{array}$ & $\overline{\text { Sūtras }}$ & $\begin{array}{l}\text { Local, typical } \\
\text { Austro-As. like } \\
\text { prefix (kar-; as } \\
\text { in jar-tila: tila) }\end{array}$ & $\begin{array}{l}\text { Cf. Meso- } \\
\text { potamian } \\
\text { kapazum; > Gr. } \\
\text { karposos }\end{array}$ & $\begin{array}{l}\overline{\mathrm{I} 317} \\
\text { probal } \\
\text { loanw }\end{array}$ \\
\hline Sugar cane & $\overline{\mathrm{ikșu}}$ & $\begin{array}{l}1.2 \text { AV+ } \\
\text { C.N.India }\end{array}$ & $\begin{array}{l}\text { Local word in } \\
\text { several dialect } \\
\text { forms: iksu, } \\
\text { *ukșu, *rikṣu, } \\
\text { *akṣu < ṛșu? }\end{array}$ & $\begin{array}{l}\text { Cf. RV +; } \\
\text { name: Ikṣvāku; } \\
\text { classs. } \\
\text { ikșvāku 'bitter } \\
\text { gourd, Citrillus } \\
\text { colocynthis'; } \\
\text { AAs.? H. } \\
\text { Berger WZKS } \\
\text { 3,73 sqq } \\
\end{array}$ & $\begin{array}{l}\overline{\text { I 185: }} \\
\text { opinic } \\
\text { I } 185 \\
\text { Proba } \\
\text { foreig }\end{array}$ \\
\hline$\overline{\overline{\text { (Sugar) }}}$ & $\begin{array}{l}\text { śarkarā } \\
\text { 'pebbles' }\end{array}$ & $\overline{1.2 . \mathrm{AV}+}$ & $\begin{array}{l}\text { Later: Class, } \\
\text { Skt. 'sugar' }\end{array}$ & $\begin{array}{l}\text { Greek krokalē } \\
? ; \\
\text { AAAs. prefix śar- } \\
?\end{array}$ & $\begin{array}{l}\text { EWA } \\
619\end{array}$ \\
\hline $\begin{array}{l}\text { AFRICAN } \\
\text { Origin }\end{array}$ & & & & & \\
\hline $\begin{array}{l}\text { Setaria italica (L.) } \\
\text { Pal. Beauv. = } \\
\text { Panicum italicum } \\
\text { L. }\end{array}$ & $\begin{array}{l}\text { priyáṅgu } \\
\text { priyañgukā }\end{array}$ & $\begin{array}{l}1.2 / 3 \\
1.4 \mathrm{Br} .\end{array}$ & $\begin{array}{l}\text { See Witzel, } \\
\text { 1999: } \\
\text { Popular etym. } \\
\text { for (Drav.) } \\
\text { karigu, etc. }\end{array}$ & $\begin{array}{l}\text { CDIAL 8976; } \\
\text { Cf. s.v. kangu } \\
\text { (discuss. above; } \\
\text { see below on } \\
\text { Skt. kangu) } \\
\end{array}$ & $\begin{array}{l}\overline{\text { II } 190} \\
\text { foreig } \\
\text { word? } \\
\text { Cf. B } \\
\text { pron }\end{array}$ \\
\hline $\begin{array}{l}\text { Panicum miliaceum } \\
\text { L.; }\end{array}$ & áṇu & $1.2 / 3 \mathrm{TS}$ & $\begin{array}{l}\text { Adaptation } \\
\text { from priyangu, }\end{array}$ & $\begin{array}{l}\text { Cf. anva/ etc., } \\
\text { RV }\end{array}$ & $\begin{array}{l}\overline{\text { I 55 }} \\
\text { Uncle }\end{array}$ \\
\hline
\end{tabular}




\begin{tabular}{|c|c|c|c|c|c|}
\hline & & C.N.India & $\begin{array}{l}\text { kan்gu, see } \\
\text { Witzel } 1999\end{array}$ & & \\
\hline Millet & $\begin{array}{l}\text { varjarī :: } \\
\text { *bājjara }\end{array}$ & $\begin{array}{l}1.5 \mathrm{HSS} \\
\text { C.N.India }\end{array}$ & $\begin{array}{l}\text { CDIAL } 9201 \\
\text { Panj. bājrā etc. }\end{array}$ & *bājara, *bājjara & $\begin{array}{l}\overline{\text { III } 45 i} \\
\text { clear }\end{array}$ \\
\hline & & & & & \\
\hline ATTESTED & $\overline{\mathrm{ONNY}}$ & LATER: & *OIA, MIA, & 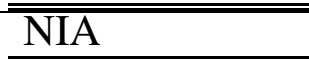 & \\
\hline SW ASIAN origin & & & & & \\
\hline Chickpea & $\begin{array}{l}\text { cana(ka) } \\
\text { Mb̀h, Susr. }\end{array}$ & & $\begin{array}{l}\text { CDIAL } 4579 \\
\text { Pali, Pkt., NIA } \\
\end{array}$ & & $\begin{array}{l}\overline{\overline{\text { III 17' }}} \\
\text { uncles }\end{array}$ \\
\hline$\overline{\text { Grass pea }}$ & $\begin{array}{l}\text { *k(h)ēsārī } \\
<> \\
\text { késara 'hair, } \\
\text { filament'YY, } \\
\text { cf. kesānī 'a' } \\
\text { plant'KausS. }\end{array}$ & & & $\begin{array}{l}\text { CDIAL } 3925 \\
\text { *k(h)ēsārī; } \\
\text { *kēsāarī only > } \\
\text { Hindi; not in } \\
\text { Skt. }\end{array}$ & $\begin{array}{l}<>\mathrm{Cf} \\
\text { cf. ke } \\
\text { CDIA } \\
3475 \\
\text { 'mane } \\
\text { (keśa } \\
\end{array}$ \\
\hline$\overline{\text { Pea }}$ & $\overline{* \text { mattara }}$ & & & $\begin{array}{l}\text { CDIAL } 9724 \\
\text { Only NIA! }\end{array}$ & \\
\hline \multicolumn{6}{|l|}{ 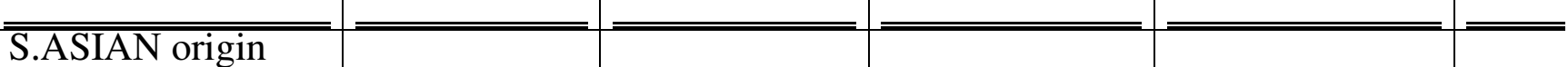 } \\
\hline Rice (add.) & $\overline{\overline{\mathrm{IA}} * \text { cāmala }}$ & $\begin{array}{l}\text { Prakrit+cā̄ulla }, \\
\text { etc. }\end{array}$ & $\begin{array}{l}\text { Cf. Tibeto- } \\
\text { Burm. dza 'to } \\
\text { eat', Benedict, } \\
\text { Conspectus: 28, } \\
\text { \#66; Austri- } \\
\text { Thai *c'amaq, } \\
\text { Benedic, Au- } \\
\text { Jp. }\end{array}$ & $\begin{array}{l}\text { From Austric? } \\
\text { But cf. Drav. } \\
\text { [c]aval, etc. } \\
\text { DEDR 2391, } \\
\text { and } 268 \text { [zero+] } \\
\text { avi (-v, -nt-) 'to } \\
\text { steam boil' }\end{array}$ & 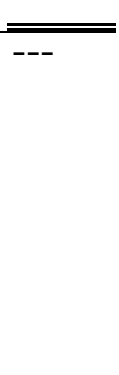 \\
\hline Foxtail millet & kaṅgu & $\begin{array}{l}\text { Brhatsam- } \\
\text { hitā, 550 CE }\end{array}$ & $\begin{array}{l}\text { Cf. Bantu : } \\
\text { *kóngó, } \\
\text { *pungu; } \\
\text { MW 1999: cf. } \\
\text { priyañgu, anu }\end{array}$ & $\begin{array}{l}\text { PMu. (h)oxy is } \\
\text { too different; } \\
\text { ditto Drav. } \\
\text { DEDR } 1242 \\
\text { kampu, } 2163 \\
\text { kura, } \\
\text {... }\end{array}$ & $\begin{array}{l}\text { III } 43 \\
\text { Forei } \\
\text { word? }\end{array}$ \\
\hline Urd : vigna mungo & $\begin{array}{l}\text { *udidda } \\
\text { 'a pulse' }\end{array}$ & Pkt. uḍida & $\begin{array}{l}\text { Pkt. udidia } \\
\text { CDIAL } 1693 \text {; } \\
\text { cf. udidda } \\
\text { CDIÁ } 14302, \\
\text { Mar. udid, } \\
\text { Hindi ự(a)d }\end{array}$ & $\begin{array}{l}\text { *udidda < Tam. } \\
\text { u.r.untu 'black } \\
\text { gram, } \\
\text { phaseolus } \\
\text { mungo', Kan. } \\
\text { urdu, DEDR } \\
690\end{array}$ & $\overline{--}$ \\
\hline
\end{tabular}




\begin{tabular}{|c|c|c|c|c|c|}
\hline Cucumber & kṣīraka & Lex. only & $\begin{array}{l}\text { CDIAL: NIA } \\
3667,3698, \\
3703 \\
\end{array}$ & & $\begin{array}{l}\text { III 13' } \\
\text { etym? } \\
\text { kșīra“1 } \\
\text { etc. }\end{array}$ \\
\hline$\overline{\text { Bitter gourd }}$ & $\begin{array}{l}\text { kāravella, } \\
\text { *kārella } \\
\text { 'Momordica } \\
\text { charantia' }\end{array}$ & $\overline{\text { Suśruta }}$ & $\begin{array}{l}\text { CDIAL 3061 } \\
\text { Pali kāravella, } \\
\text { Pkt. kāriyallaï;- } \\
\text { kārellaya, etc. }\end{array}$ & $\begin{array}{l}\text { Drav. origin of } \\
\text { kārella ‘black } \\
\text { spear' kāṇ̣̂īra }\end{array}$ & $\begin{array}{l}\overline{\text { III } 85} \\
\text { loan v }\end{array}$ \\
\hline Ivy gourd & $\begin{array}{l}\text { kunduru ' } \\
\text { Boswellia } \\
\text { thurifera, its } \\
\text { raisin' } \\
\text { (incense } \\
\text { tree); }\end{array}$ & $\begin{array}{l}\text { Brhatsamhitā, } \\
\text { 55ं0 CE; } \\
\text { kundurukā } \\
\text { Suśruta }\end{array}$ & $\begin{array}{l}\text { CDIAL } 3298 \\
\text { kunda 'raisin' } \\
\text { kānduruka } \\
\text { 'Boswellia } \\
\text { thurifera' } \\
\text { MIA, NIA }\end{array}$ & $\begin{array}{l}\text { kunduru < } \\
\text { Iranian? -- } \\
\text { kunduru } \\
\text { mukunda } \\
\text { 'raisin of } \\
\text { Bosw.'< } \\
\text { Austro-As.? }\end{array}$ & $\begin{array}{l}\text { III 10r } \\
\text { kundu } \\
\text { contes } \\
\text { Irania } \\
\text { Austr، } \\
\text { origin }\end{array}$ \\
\hline$\overline{\text { Luffa/sponge gourd }}$ & *tōrīi 'gourd' & $\overline{\text { *tubara? }}$ & $\begin{array}{l}\text { CDIAL 5977; } \\
\text { Possibly < } \\
\text { *tubara/tumba }\end{array}$ & $\begin{array}{l}\text { Found in } \\
\text { Northern NIA: } \\
\text { Panj. tōrī, etc. }\end{array}$ & $\overline{----}$ \\
\hline Okra & $\begin{array}{l}\text { bhinḍ̄ā } \\
\text { 'vegetable } \\
\text { Abel- } \\
\text { moschus } \\
\text { esculentus' }\end{array}$ & $\overline{\text { Pañcatantra }}$ & $\begin{array}{l}\text { CDIAL 9492; } \\
\text { NIA }\end{array}$ & & $\begin{array}{l}\overline{\text { III 36! }} \\
\text { expl.' }\end{array}$ \\
\hline$\overline{\overline{\text { Bread }}}$ & *rotṭa & $\begin{array}{l}\text { rotikāa } \\
\text { Bhagavat- } \\
\text { Purânạa }\end{array}$ & $\begin{array}{l}\text { CDIAL } 10837 \\
\text { Pkt. rottta 'rice } \\
\text { flour' } \\
\text { Deśinamāāa ; } \\
\text { rotțaga, ruttiāa } \\
\text { 'bread' }\end{array}$ & $\begin{array}{l}\text { Cf. *roñc, } \\
\text { CDIAL } 10836 \\
\text { 'to crush, } \\
\text { grind', Pkt. } \\
\text { romcaï }\end{array}$ & $\begin{array}{l}\text { III } 43 \text { ' } \\
\text { Connt } \\
\text { rot 'to } \\
\text { beat' : } \\
\text { Pkt. rc }\end{array}$ \\
\hline Areca nut (add.) & 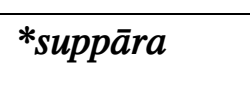 & NIA only & $\begin{array}{l}\text { CDIAL 13482, } \\
\text { Hindi supāri }\end{array}$ & & --- \\
\hline $\begin{array}{l}\text { Sheep; } \\
\text { Most other } \\
\text { names for } \\
\text { domestic animals } \\
\text { are IA. }\end{array}$ & $\begin{array}{l}\text { bheḍra/ } \\
\text { meḍra/ } \\
\text { meṇdha } \\
\text { 'ram' } \\
\text { Lex. }\end{array}$ & $\begin{array}{l}\text { Pkt. menthī̄ } \\
\text { ‘sheep’; } \\
\text { mindha(ka) } \\
\text { Buddh. Skt }\end{array}$ & $\begin{array}{l}\text { menḍha, } \\
\text { mețua, } \\
\text { meḍhra(ka), } \\
\text { Lex. }\end{array}$ & $\begin{array}{l}\text { MIA, NIA; } \\
\text { CDIAL 10310; } \\
\text { Cf. } 9604,9606\end{array}$ & $\begin{array}{l}\text { III } 41 \text {. } \\
\text { appart } \\
\text { foreig } \\
\text { words } \\
\text { conne } \\
\text { with } \\
\text { bheda } \\
\text { bhedir: } \\
\text { bhedi }\end{array}$ \\
\hline
\end{tabular}

